\title{
RESISTÊNCIA DE UNIÃO ENTRE TRÊS SISTEMAS CERÂMICOS DE USO ODONTOLÓGICO COM UMA LIGA DE PALÁDIO-PRATA.
}

JULIANO MILCZEWSKY SCOLARO

\begin{abstract}
Dissertação apresentada à Faculdade de Odontologia de Bauru, da Universidade de São Paulo, como parte dos requisitos para a obtenção do título de Mestre em Odontologia, área de Reabilitação Oral.
\end{abstract}

BAURU

2000 


\section{RESISTÊNCIA DE UNIÃO ENTRE TRÊS SISTEMAS CERÂMICOS DE USO ODONTOLÓGICO COM UMA LIGA DE PALÁDIO-PRATA.}

JULIANO MILCZEWSKY SCOLARO

Dissertação apresentada à Faculdade de Odontologia de Bauru, da Universidade de São Paulo, como parte dos requisitos para a obtenção do título de Mestre em Odontologia, área de Reabilitação Oral.

Orientador: Prof. Dr. Accácio Lins do Valle

BAURU

2000 


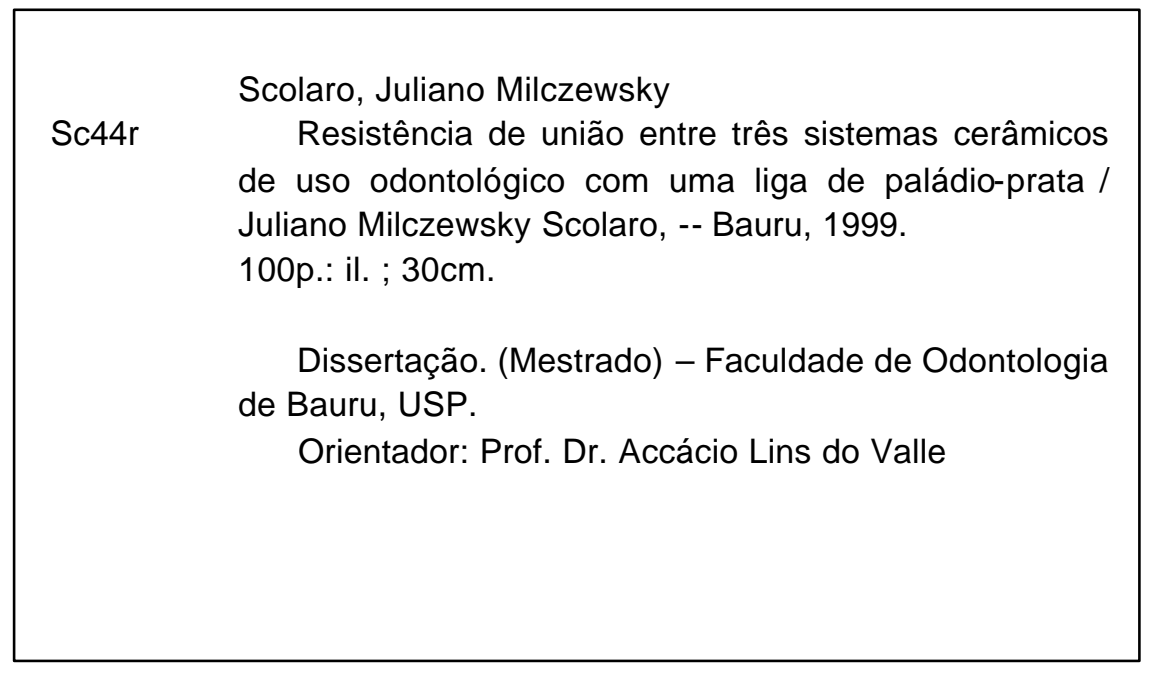


23 de junho de 1973

Nascimento

Curitiba - PR

Filiação

HUMBERTO SCOLARO JUNIOR

RENATA MILCZEWSKY SCOLARO

$1990-1994$

Curso de Graduação em Odontologia na Faculdade de Odontologia de Bauru, Universidade de São Paulo.

$1998-2000$

Curso de Pós-graduação em Reabilitação Oral - Prótese, nível de Mestrado, na Faculdade de Odontologia de Bauru da Universidade de São Paulo.

Associações

APCD - Associação Paulista de Cirurgiões-Dentistas.

APG - Associação dos Pós-Graduandos da Faculdade de Odontologia de Bauru. 
“ Tua é, Senhor, a magnificência, e o poder, e a honra, e a vitória, e a majestade; porque teu é tudo quanto há nos céus e na terra, teu é Senhor, o reino, e tu te exaltaste sobre todos como chefe.

E riquezas e glória vêm de diante de ti, e tu dominas, sobre tudo, e na tua mão há força e poder; e na tua mão está o engrandecer e dar força a tudo.

Agora pois, ó Deus nosso, graças te damos, e louvamos o nome da tua glória."

Agradeço a DEUS, pela realização deste trabalho. 
Aos meus pais, Humberto e Renata, responsáveis pela minha formação humana, que com seus exemplos de virtudes, seu carinho e apoio incondicionais, me ajudaram a manter sempre vivas a esperança e a motivação.

Aos meus irmãos Rodrigo e Rafael, por seu apoio, carinho, incentivo e amizade durante todos estes anos de convivência

À minha avó Érica, por seu apoio, carinho e perseverança em todos os momentos.

Dedico este trabalho. 
À minha esposa Hérika, que com o mesmo amor, carinho, paciência e compreensão que me conquistaram, contribuiu para a realização deste momento. Quando voltei para Bauru achei que fazer o curso seria difícil, mas uma vez aqui, descobri que o difícil mesmo é ficar longe da pessoa que amo. Apesar do sacrifício de estarmos distantes durante esse tempo, você nunca deixou de estar sempre presente no meu pensamento, pois levo você o tempo todo no meu coração.

A você, dedico este trabalho. 
Ao meu orientador, Prof. Dr. Accácio Lins do Valle, pela capacidade, presteza e atenção dispensados durante todo o curso. Pela confiança em mim depositada, pelo estímulo e crença no meu potencial.

Pela sinceridade, companheirismo e principalmente pela amizade durante todos esses anos de convivência.

Meu mais profundo respeito, minha gratidão e amizade. 
Ao Prof. Dr. Luiz Fernando Pegoraro, pela amizade, respeito e companheirismo, pela oportunidade de convivência antes e durante todo o curso.

Ao Prof. Dr. Gerson Bonfante, pela orientação segura e amizade.

Meu reconhecimento e gratidão. 
Aos professores do Departamento de Prótese da Faculdade de Odontologia de Bauru - USP, pela amizade, coleguismo e respeito.

Ao amigo e irmão José Arimatéia Rabelo, pela ajuda e orientação na confecção dos corpos de prova.

Ao Prof. Dr. José Henrique Rubo, pela presteza no auxílio com a análise estatística e abstract deste trabalho.

À Faculdade de Odontologia de Bauru e à Comissão de Pós-Graduação, por possibilitarem a realização do curso.

À FAPESP pela concessão da bolsa de estudos (processo 98/06880-0), sem a qual o curso de Mestrado seria impossível, bem como a realização deste trabalho.

Minha sincera gratidão 
Ao Paulo Henrique Rossetti, pela ajuda na discussão deste trabalho.

Aos funcionários do Departamento de Prótese, Edna, Ângela, Lilian, Marcelo, Reivanildo, Didi, Geraldo e Luzia, pela atenção e gentileza em todos estes anos de convívio.

Aos funcionários da Pós-Graduação, Neide, Heloísa, Giane, Débora, Cleusa e Ana, pela paciência e colaboração.

Aos funcionários da Biblioteca, em especial a Vera, Rita, Cibele e Ademir, pela atenção constante e disponibilidade para ajudar.

À bibliotecária Valéria Cristina Trindade Ferraz, pela revisão bibliográfica e normatização técnica deste trabalho.

Aos pacientes, por sua confiança e colaboração.

A todos aqueles que colaboraram para a realização deste trabalho.

Meu muito obrigado. 
Aos colegas de Doutorado, Luiz, Materson, João, Hideki, Henrique, Sérgio, Luciano e Daniel, pelo convívio, amizade e inspiração.

Aos colegas do curso de Mestrado, Letícia, Daniela, Anuar, Carlinhos, Mário, Murilo, Sérgio, Vinícius Porto, Vinícius Janson, Vagner e Andréa. Por todos momentos de convivência, pela troca de experiências, pela compreensão e amizade.

Ao meu "padrinho" William Barnabé, pela amizade sincera, presteza e orientação.

Ao "tio" Nelson, pela alegria de nossa convivência e amizade.

Meu carinho, admiração e amizade. 


\section{SUMÁRIO}

LISTA DE FIGURAS X xii

LISTA DE TABELAS xiv

RESUMO X xv

1 INTRODUÇÃO

2 REVISÃO DA LITERATURA

3 PROPOSIÇÃO

4 MATERIAIS EMÉTODOS 53

4.1 Confecção dos padrões de cera 56

4.2 Inclusão e fundição 58

4.3 Tratamento dos padrões metálicos 60

4.4 Aplicação da cerâmica 62

4.5 Testes de resistência ao cisalhamento 65

$\begin{array}{lll}5 & \text { RESULTADOS } & 67\end{array}$

$\begin{array}{lll}6 & \text { DISCUSSÃO } & 73\end{array}$

7 CONCLUSÃO $\quad 86$

REFERÊNCIAS BIBLIOGRÁFICAS 88

$\begin{array}{ll}\text { ABSTRACT } & 99\end{array}$ 


\section{Lista de figuras}

Figura 1 - Esquema gráfico das dimensões da matriz de aço inoxidável

Figura 2 - Esquema gráfico da configuração do teste de cisalhamento

Figura 3-Conjunto de componentes da matriz:

A - Base para adaptação na máquina de ensaios

B - Matriz de aço inoxidável

C - Pino metálico para remoção dos padrões e corpos de prova

D - Disco espaçador para padronização dos corpos de prova

Figura 4 - Corte esquemático do conjunto de componentes da matriz:

A - Base para adaptação na máquina de ensaios

B - Matriz de aço inoxidável

C - Pino metálico para remoção dos padrões e corpos de prova

D - Disco espaçador para padronização dos corpos de prova

Figura 5-A - Matriz de aço inoxidável

B - Padrão de cera posicionado no interior da matriz

Figura 6-A -Corte esquemático da matriz de aço inoxidável

B - Padrão de cera posicionado no interior da matriz 57

C - Disco espaçador posicionado

Figura 7- Posicionamento dos padrões de cera no pino formador de condutos de alimentação

Figura 8- Posicionamento do conjunto dentro do anel de silicone

Figura 9-A - Padrão de cera

B - Padrão metálico

60

Figura 10 - Padrão de cera adaptado e posicionado no interior da matriz

Figura 11 - Corte esquemático mostrando:

Figura 12 - Remoção do padrão metálico com a camada de cerâmica aplicada

Figura 13 - Corpos de prova concluídos

Figura 14 - Com o disco espaçador posicionado, apenas a porção cerâmica permanece para fora 
Figura 15 - A - Corte esquemático da matriz de aço inoxidável 66

B - Disco espaçador posicionado 66

C - Porção cerâmica recebendo a força de compressão 66

D - Ponta ativa exercendo pressão sobre a interface 66

Figura 16 - Gráfico demonstrativo das áreas de superfície de teste dos corpos de $\begin{array}{ll}\text { prova para os três sistemas cerâmicos } & 69\end{array}$

Figura 17-Gráfico demonstrativo das médias e desvio padrão para os três sistemas $\quad 71$ 


\section{Lista de tabelas}

Tabela 1 - Temperaturas e tempos de queima dos sistemas cerâmicos

Tabela 2 - Valores obtidos em MPa para os testes de resistência ao cisalhamento com os corpos de prova do sistema Ceramco (duas camadas de opaco em pasta + duas camadas de corpo)

Tabela 3 - Valores obtidos em MPa para os testes de resistência ao cisalhamento com os corpos de prova do sistema Noritake (duas camadas de opaco em pasta + duas camadas de corpo)

Tabela 4 - Valores obtidos em MPa para os testes de resistência ao cisalhamento com os corpos de prova do sistema Vita VMK-68 (duas camadas de opaco em pasta + duas camadas de corpo)

Tabela 5 - Parâmetros amostrais 


\section{RESUMO}

Avaliou-se a resistência ao cisalhamento da união metalocerâmica, de três diferentes sistemas cerâmicos de uso odontológico (Ceramco, Noritake e Vita VMK-68) aplicados sobre uma liga de paládio-prata (Pors-on 4), utilizando-se para isto, forças de compressão. Utilizando-se a metodologia descrita por CHONG; BEECH; $\mathrm{CHEM}^{19}$, modificada por BATISTA ${ }^{7}$, foram confeccionados 30 padrões metálicos divididos em três grupos de dez espécimes, sob os quais foi aplicada a cerâmica. Para a confecção dos corpos de prova, aplicação da cerâmica e realização dos testes de cisalhamento, utilizou-se uma matriz de aço inoxidável, em formato cilíndrico, com uma perfuração central de tamanho predeterminado, obtendo-se assim, corpos de prova padronizados. Após a fundição os padrões metálicos foram jateados com óxido de alumínio $50 \mu m$ e levados ao forno sem vácuo a $980^{\circ} \mathrm{C}$ por dez minutos para a oxidação prévia. Recolocados novamente no interior da matriz, receberam duas camadas de cerâmica opaca e duas camadas de cerâmica de corpo. Em seguida foram realizados os testes de resistência ao cisalhamento em uma máquina de tração e compressão, utilizando-se uma célula de carga de 100Kgf e velocidade de $0,5 \mathrm{~mm} / \mathrm{min}$. As médias dos valores de resistência de união obtidas foram de 28,212MPa para o sistema Ceramco, 28,963MPa para o Noritake e 24,110MPa para o Vita VMK-68. Quando submetidos à análise de variância a um critério, não foram observadas diferenças estatisticamente significantes, o que nos levou à conclusão de que todos os sistemas possuem uma características de união metalocerâmica satisfatórias quando utilizados em conjunto com a liga selecionada. Além disso, os resultados são semelhantes aos descritos na literatura e se encontram além das forças necessárias para provocar a falha dos mesmos. 


\section{INTRODUÇÃO}

As cerâmicas foram provavelmente os primeiros materiais produzidos artificialmente pelo ser humano, como da mesma forma, foram os primeiros materiais a serem estudados cientificamente pelo homem.

A palavra cerâmica tem origem do termo grego keramos, que significa "coisa queimada", e o fogo foi descoberto pelo homem há cerca de 400.000 anos. Em algum lugar, em alguma época neste intervalo de tempo, esta "coisa queimada" foi acidentalmente produzida.

Com o passar do tempo, a habilidade em se lidar com este material, bem como a sua gama de utilizações aumentaram, e finalmente em meados do século XVIII, iniciou-se de forma empírica a utilização das cerâmicas na Odontologia.

Inicialmente, seu uso ficou restrito à confecção de dentes artificiais para a construção de dentaduras. Mais modernamente, no final do século passado e metade deste, iniciou-se a confecção de coroas puras de cerâmica para a reposição de dentes individuais.

Porém, somente em 1956 começaram a aparecer as primeiras publicações mais esclarecedoras sobre as técnicas de aplicação da cerâmica sobre ligas de ouro, quando SILVER et al. ${ }^{55}$ iniciam os estudos sobre os fenômenos de adesão da cerâmica à superfície metálica.

Nesta mesma época, JOHNSTON et al. ${ }^{27}$ ressaltam a preocupação em se determinar por meio de testes físicos, a capacidade de união da cerâmica. Para que fosse feita essa avaliação, realizaram uma adaptação do teste de Swartz e Phillips para os cimentos dentais. 
O primeiro relato sobre ligas especialmente preparadas para essa técnica foi feito por BRECKER ${ }^{11}$, em 1956, onde se buscou a compatibilização das propriedades térmicas da cerâmica e da infra-estrutura metálica.

Desde o início da utilização da cerâmica aplicada sobre o metal, houve uma grande preocupação com a natureza da ligação metalocerâmica, termo este introduzido por SKINNER; PHILLIPS ${ }^{57}$.

Existe um consenso entre os estudiosos, de que a adesão do metal com a cerâmica se deve a três tipos de união:

- Química - Considerada como fonte de união primária, está relacionada com as ligações iônicas, covalentes e metálicas. É a principal forma pela qual acontece a união metal/cerâmica, por troca de óxidos formados entre o metal e os elementos oxidáveis na cerâmica.

- Física - Fonte de união secundária, é promovida pelas ligações de Van der Walls, que são forças de atração entre dois átomos polarizados em contato íntimo, mas sem a troca de elétrons, como visto na união química. Este tipo de união depende da "molhabilidade" da liga, independentemente do tipo de metal. Quanto mais molhável a liga, mais forte será a união metalocerâmica, e este molhamento dependerá do tipo de tratamento e acabamento da superfície metálica.

- Mecânica - Este tipo de ligação depende da forma de contorno, do estado da superfície e de forças de compressão originadas pela diferença de coeficientes de expansão térmica da cerâmica e do metal. As irregularidades microscópicas 
presentes na superfície da liga permitem que durante a cocção da cerâmica, devido ao seu estado semelhante a um líquido viscoso e adesivo, esta penetre nas irregularidades, proporcionando o imbricamento que resulta em retenção mecânica. Além disso, as ligas e os sistemas cerâmicos apresentam diferenças entre seus coeficientes de expansão térmica. Como o coeficiente das ligas é ligeiramente maior, durante o resfriamento da cerâmica, o metal contrai-se mais e mais rapidamente do que aquela, promovendo tensões de compressão residuais na cerâmica, ocasionando uma resistência de união adicional, por compressão.

Com o desenvolvimento de novos tipos de materiais, houve a necessidade de se avaliar esse tipo de união por meio de testes, especialmente idealizados.

O primeiro teste criado para este fim foi o proposto por SHELL; NIELSEN ${ }^{54}$, em 1962. Dez anos depois, em 1972, SCED; MCLEAN ${ }^{53}$ idealizaram um outro tipo de teste, que não foi muito bem aceito pela dificuldade de confecção dos corpos de prova e por não incorporar tensões residuais inerentes à estrutura metalocerâmica, impedindo a reprodução fiel dos fenômenos presentes neste tipo de sistema.

Mais recentemente, devido ao aumento de preço do ouro utilizado para a confecção de ligas odontológicas, buscourse a utilização de outros elementos para a composição das ligas metalocerâmicas. Um desses elementos é o Paládio, metal nobre consideravelmente mais barato que o ouro e a platina. Seu ponto de fusão de $1552^{\circ} \mathrm{C}$ é muito elevado para a utilização odontológica, devendo-se diminuir 
esse ponto de fusão, com a adição de outros metais como o ouro, estanho, índio, prata, gálio e cobre. Outros elementos são comumente adicionados para melhorar as propriedades físicas, químicas e de processamento. Muitas ligas têm adicionadas em sua composição, "refinadores de grãos", que são elementos com ponto de fusão mais elevado e que atuam como núcleos de cristalização, possibilitando a formação de grãos de tamanho reduzido. Esta característica de uma liga possuir grãos de pequenas dimensões resulta em um material com melhores propriedades mecânicas e químicas, contribuindo para o sucesso das restaurações metalocerâmicas.

Porém, a utilização de Pd nas ligas implica na contra-indicação de revestimentos contendo carbono, pois esse elemento interage muito facilmente com o paládio durante a fundição, provocando o aparecimento de impurezas, que durante a cocção da cerâmica contribuirão para a diminuição da resistência de união metalocerâmica.

Além disso, a presença de prata em determinadas marcas comerciais, segundo alguns autores ${ }^{9,37}$ pode provocar efeitos de descoloração ou esverdeamento da cerâmica devido à evaporação de prata durante a cocção, exigindo o desenvolvimento de sistemas cerâmicos livres desse tipo de interferência e a avaliação dos sistemas atuais.

Muitos autores também indicam a utilização da oxidação prévia nas ligas nobres. Sabe-se que este procedimento é imprescindível para a união metalocerâmica em ligas à base de ouro. Porém, segundo BÖNING; WALTER ${ }^{9}$; MACKERT; RINGLE; FAIRHURST ${ }^{37}$, nas ligas à base de paládio, não há a formação de uma camada de óxidos superficiais notável a ponto de indicar a união química do metal com a cerâmica. 
Com o desenvolvimento de novos sistemas cerâmicos no mercado odontológico e a maciça utilização de ligas de paládio, principalmente as de Pd-Ag, torna-se necessária uma avaliação das características de trabalho destes materiais em associação, inclusive utilizando-se uma nova metodologia para confecção dos corpos de prova e realização dos testes. 


\section{REVISÃO DA LTERATURA}

JOHNSTON; DYKEMA; CUNNINGHAM ${ }^{27}$, em 1956, comunicaram a execução de testes efetuados com cerâmicas aplicadas sobre metal. Foram realizados testes de corrosão, de adesão, de penetração de corantes, resistência à flexão, resistência da cerâmica, dentre outros. Para os testes de união foi utilizado o método modificado, descrito por Swartz e Phillips, para determinar as características adesivas dos cimentos dentais. Esses testes, feitos com liga de ouro especial para fundição e cerâmica opaca, apresentaram resultados que variaram de 4850 a 7050psi, com média de 5620psi. Em todos os casos, a fratura ocorreu internamente à camada cerâmica e não na interface, demonstrando, segundo os autores, que a união metalocerâmica seria mais resistente do que a própria resistência coesiva da cerâmica. Os autores afirmam que com esta técnica um grande passo para frente estava sendo dado no campo das restaurações dentais, e antecipam que no futuro ela teria uma larga e diversificada aplicação.

SILVER; KLEIN; HOWARD ${ }^{55}$, em 1956, afirmaram que a adesão da cerâmica com o metal se dá de forma mecânica, às custas de uma adesão molecular. Tal afirmação foi feita com base no desenvolvimento de materiais com coeficientes de expansão e contração térmica iguais. Os autores descrevem que durante a fusão da cerâmica a água de cristalização é eliminada a $500^{\circ} \mathrm{C}$ enquanto a contração e a condensação do volume de substâncias argilosas como o caolin, feldspato e quartzo ocorre a $871^{\circ} \mathrm{C}$. Quando a cerâmica e a subestrutura metálica atingem o máximo de expansão durante o processo de fusão, os poros do metal são 
consideravelmente alargados. Certas substâncias presentes na cerâmica, principalmente agentes fundentes, tornam-se liquefeitos e preenchem os múltiplos poros alargados, mesclando-se ao metal, interpenetrando a estrutura cristalina da liga, o que resulta numa forte união mecânica. Segundo os autores, quando o processo de fusão é feito adequadamente, a união entre a cerâmica e o metal é tão grande que só poderá ser rompida por desgaste, dobramento do metal ou pela completa dissolução da cerâmica em ácido hidrofluorídrico. Com base nesta filosofia, pode-se afirmar que a cerâmica odontológica não deve ser considerada um material frágil.

Ainda em 1956, BRECKER ${ }^{11}$ afirmava que, apesar das próteses metaloplásticas satisfazerem os anseios estéticos dos pacientes, as suas limitações como descolorações e mudanças de forma devido à abrasão, fizeram com que os pesquisadores desenvolvessem novas técnicas, novos materiais, ligas e œrâmicas, para que os aborrecimentos causados pela fratura das cerâmicas e a descoloração dos plásticos em coroas veneer, bem como a demanda pela estética dos pacientes pudessem ser resolvidos. Desta maneira, os sistemas cerâmicos assumiriam seu lugar de direito na Odontologia restauradora. Segundo o autor, a cerâmica poderia ser fundida sobre vários tipos de metais, como ligas de platina e irídio, ligas de paládio e ligas de ouro. As ligas de ouro para metalocerâmica foram consideradas como as melhores em termos de união metal/cerâmica, devido ao coeficiente de expansão térmica da liga ser compatível com o sistema cerâmico, não ocorrendo tensões que originariam trincas na cerâmica. Adicionalmente, a aplicação de um 
agente umectante e uma fina camada de cerâmica opaca, produziria uma restauração esteticamente aceitável e com excelente adaptação marginal.

JOHNSTON; DYKEMA; CUNNINGHAM ${ }^{28}$, em continuação do trabalho anterior, descrevem em 1958, a utilização de cerâmica para confecção de coroas tipo "venner", onde a porção estética normalmente confeccionada em resina acrílica, seria substituída por cerâmica. No mesmo trabalho, são descritos os métodos para confecção dos preparos, quantidade de desgaste e tipo de término cervical. Uma modificação deveria ser efetuada no incisivos, onde o término cervical deveria ser na forma de chanfrado ou bisel. Os autores comentam que existem dificuldades para os iniciantes, principalmente no que diz respeito à seleção da cor, havendo a necessidade da confecção de várias restaurações para que se obtivesse o domínio do material. São descritas também, algumas técnicas para coloração extrínseca, a fim de se conseguir o efeito de separação e individualização em próteses fixas extensas.

SMITH et al. ${ }^{58}$, em 1959, consideraram discutíveis os métodos e testes disponíveis para se determinar as propriedades das cerâmicas. Nos testes realizados, os resultados demonstraram que a resistência da união metalocerâmica com ligas de ouro é mais forte que a força de coesão da cerâmica. Portanto, a utilização de ligas áuricas combina a resistência do metal com a estética das cerâmicas, nos mais diversos tipos de aplicação da prótese fixa. 
Em 1961, BASSMAN realizou avaliações de prótese metalocerâmicas por um período de três anos. Os resultados foram muito satisfatórios, confirmando que a cerâmica fundida sobre o ouro é o maior desenvolvimento das restaurações dentais desta época. Segundo o autor, a realização de testes laboratoriais para avaliar a resistência da união metalocerâmica serviria para elucidar qualquer dúvida sobre a utilização destes materiais em restaurações. Afirmou também que o opaco deveria ser aplicado corretamente para que se pudesse obter melhor desempenho mecânico e estético.

SHELL; NIELSEN ${ }^{54}$, em 1963, salientaram o avanço dos materiais restauradores cerâmicos e dos processos de aplicação sobre o metal, assim como a preocupação com a natureza e resistência da união metalocerâmica. Desta forma, descrevem os primeiros testes cientificamente apropriados para a avaliação da resistência de união metalocerâmica. O teste era feito pela aplicação de cerâmica em uma haste metálica, que era levada a uma máquina de tração. Os corpos de prova eram confeccionados com base em três princípios: 1) Ausência de forças de tensão, devido aos diferentes coeficientes de expansão térmica, 2) Ausência de tensão na interface de união durante o teste. 3) Ausência de falhas coesivas do material. Os testes utilizando este tipo de metodologia demonstraram que além da resistência de união metalocerâmica, as variações químicas das ligas têm efeito significativo na resistência ao cisalhamento. Foram utilizados condicionadores de metal com a finalidade de se obter uma camada de óxidos na liga, ou seja, visando promover a união química, além daquela puramente mecânica. 
LAVINE; CUSTER ${ }^{35}$, em 1966, analisaram diferentes variáveis que afetam a resistência da união metalocerâmica com uma liga áurica. Segundo os autores, o sucesso das restaurações que utilizam metal e cerâmica estaria na dependência da forma do preparo dos dentes, na qualidade do metal utilizado e no coeficiente de expansão térmica. Além disso, qualquer força atuando na cerâmica fundida sobre o metal resultará em tensões na restauração. Se a força externa é direcionada ao metal, a tensão resultante internamente ao metal será transferida pela união para a cerâmica ou vice-versa. Acreditavam que as forças externas, resultando em tensões direcionadas ao metal poderiam ser causadas por resfriamento ou aquecimento rápidos, diferença significativa entre $\propto$ coeficientes térmicos da cerâmica e do metal ou forças aplicadas externamente resultantes da função. Com seus testes de resistência transversa utilizando ouro e cerâmica, os resultados demostraram que a cerâmica realmente ficava sob estado de tensão, permitindo a avaliação da resistência de união. As fundições que se apresentavam com mais rugosidades superficiais, obtiveram de 13 a 15\% mais resistência quando comparadas com fundições não rugosas.

Ainda em 1966, KNAPP; RYGE ${ }^{30}$ criaram um teste quantitativo com a finalidade de avaliar a resistência de união metalocerâmica, levando em consideração o efeito da atmosfera formada no interior do forno durante o ciclo de cocção da cerâmica. Os corpos de prova foram confeccionados com liga Ceramco, sendo adaptados a partir da especificação n 14 da "American Dental Association". As variáveis para aplicação da cerâmica foram: cocção sob ar , sob vácuo (pressão negativa) e sob pressão de cinco libras (pressão positiva). A avaliação nesse teste 
foi feita por meio de registros em carta gráfica, da energia necessária para formar um núcleo de fratura na secção anelar da cerâmica. Outra avaliação foi feita pelos valores de tensão máxima de fratura. Os resultados de resistência mostraram que o maior valor ocorreu quando foi feita a cocção sob vácuo. Determinou-se também que como a falha da cerâmica inicia-se na união, a carga crítica que a determina seria de cisalhamento. Desta maneira, a resistência ao cisalhamento seria o fator limitante na capacidade de suportar cargas na estrutura composta.

A natureza das forças de ligação entre a cerâmica e a liga de ouro foi estudada por VICKERY e BADINELL ${ }^{60}$, em 1968. Para estes autores, a força que produz maior fixação da cerâmica é aquela derivada da tensão de compressão gerada pela diferença no coeficiente de expansão térmica da liga e da cerâmica. Eles consideraram que a contribuição das forças de Van der Walls é insignificante. A inclusão de agentes de união aumenta a resistência de união, e estes são constituídos por traços de elementos como o ferro e estanho que durante os processos de fundição e cocção da cerâmica, tendem a precipitar-se ou segregar-se no limites granulares, promovendo uma união química.

No mesmo ano, NALLY ${ }^{45}$ analisou físico-quimicamente as cerâmicas utilizadas para aplicação sobre metal. Primeiramente foram determinadas as composições das cerâmicas Biodent, Ceramco e VMK, para opaco e para corpo. Estabeleceu-se que essas cerâmicas têm uma composição mais complexa do que as cerâmicas de média e baixa fusão clássicas. Os componentes encontrados foram o titânio, o zircônio, o estanho e o índio. Por meio de testes físicos de contração e 
expansão máximas o autor concluiu que as curvas de expansão dessas cerâmicas são diferentes mas estão próximas das curvas das ligas.

VON RADNOTH; LAUTENSCHLAGER ${ }^{62}$, em 1969, estudaram as alterações ocorridas na superfície metálica durante a cocção da cerâmica. Para isto, utilizaram sete placas que foram obtidas pela fundição de uma liga áurica. Todos os espécimes foram submetidos a um polimento com pasta diamantada de $9 \mu \mathrm{m}, 1 \mu \mathrm{m}$ e $0,25 \mu m$ subseqüentemente. Em seguida, três espécimes foram submetidos a ataque eletrolítico, e a cerâmica foi aplicada em todos os espécimes. Após a aplicação da cerâmica, todos os espécimes foram submersos em solução de ácido hidrofluórico e mantidos assim por 20 horas. Finalmente, procedeurse à observação dos corpos de prova em microscopia óptica e eletrônica, seguidas pela difração de raios-x. Todos estes procedimentos foram realizados para revelar as alterações que ocorrem na superfície metálica e serviram para que os autores tirassem as seguintes conclusões: 1) Ocorreu a formação de uma camada de $\mathrm{SnO}_{2}$ sobre a superfície metálica. 2) O íon estanho é responsável por promover o mecanismo de aderência que acontece entre metal e cerâmica. 3) A estrutura dos grãos da liga não foi afetada pela queima da cerâmica enquanto as redes dendríticas dos grãos de metal foram eliminadas.

LAUTENSCHLAGER et al. $^{34}$, em 1969, realizaram um estudo com a finalidade de determinar com precisão a natureza da união metalocerâmica utilizando uma liga de ouro. Utilizourse para o estudo um analisador eletrônico de microprova para verificar o gradiente de concentração e distribuição dos elementos 
em quatro sistemas metalocerâmicos disponíveis. Os resultados demonstraram que enquanto os principais constituintes: $\mathrm{Au}, \mathrm{Ag}, \mathrm{Pt}, \mathrm{O}$ e Si tenderam a decrescer abruptamente na interface metalocerâmica, os elementos que entram como traços: Fe, Sn e possivelmente o $\mathrm{Cu}$, foram encontrados em concentrações localizadas, com alguns micrometros na interface. Tal fato levou os autores a concluir a hipótese de que os elementos traços combinam-se com o oxigênio ou com mais elementos traços nos limites da interface para formar a união entre as duas substâncias.

Com o aumento do interesse pelo uso das metalocerâmicas em Odontologia, aumentou conjuntamente o interesse pela natureza e a resistência desse tipo de união. KELLY; ASGAR; O'BRIEN²9, em 1969, analisaram variáveis como rugosidade e oxidação prévia das superfícies da liga de ouro e avaliaram a união metalocerâmica por meio de testes de tração. Para isso, utilizaram corpos de prova que foram jateados com areia de granulação $33 \mu \mathrm{m}$ e posteriormente oxidados a uma temperatura de $982^{\circ} \mathrm{C}$ por 30 minutos. Em seguida, procedeu-se à cocção da cerâmica em três temperaturas: $1010^{\circ} \mathrm{C}, 1018^{\circ} \mathrm{C}$ e $1024^{\circ} \mathrm{C}$. Como resultados, os autores demonstraram que as superfícies oxidadas tiveram maior resistência de união do que as não oxidadas e as superfícies lisas tiveram maior resistência do que as rugosas, mesmo quando não oxidadas. Os autores concluíram que a formação de óxidos na interface metalocerâmica, criada pelos metais oxidáveis da liga com os elementos oxidáveis da cerâmica, é primordial na resistência de união, pois a camada de óxidos atuaria como um elemento de transição entre as superfícies metálica e cerâmica. 
Em 1970, ANTHONY et al. ${ }^{1}$ realizaram modificações na metodologia proposta por SHELL; NIELSEN ${ }^{54}$ e realizaram testes de resistência ao cisalhamento. Para isso, utilizaram ligas de ouro com diferentes tipos de superfície: Oxidada, não oxidada e revestida com ouro 24 quilates. Os resultados demonstraram que a resistência de união nos espécimes com superfície oxidada foi maior, que a remoção da camada de óxidos diminuiu a resistência em 30\% e que nas superfícies revestidas com ouro 24 quilates houve uma redução de $84 \%$ na resistência. Uma segunda aplicação e cocção de cerâmica foi efetuada e não se observaram alterações nos resultados. Os autores descrevem que deveria haver uma alteração contínua na química da superfície durante o ciclo de cocção da cerâmica, e seria esperado uma alteração nas condições de tensão residual que poderia influenciar na resistência de união.

MUNFORD; RIDGE ${ }^{44}$, em 1971, avaliaram as superfícies metálicas e fazem considerações sobre a preparação da superfície das ligas nobres para aplicação de cerâmica. Em primeiro lugar destacam a necessidade da superfície ser muito limpa, livre de contaminantes orgânicos, que são deixados muitas vezes pelos agentes de aglutinação usados em alguns tipos de discos de carborundo. Gases presentes e que podem ser liberados durante a queima da cerâmica também são outra causa de falhas na união e que devem ser evitados.

Em 1972, após um grande número de falhas clínicas da união metalocerâmica, SCED; MCLEAN ${ }^{53}$ avaliaram a pedido do "Comitee for Research in Dental Materials and Equipment", as causas dessas falhas. Para isso, utilizaram um 
sistema onde uma haste metálica tinha cerâmica aplicada em uma de suas extremidades. O corpo de prova era então submetido a forças de tração, e segundo os autores, esse teste fornece unicamente a medida da resistência de sistema metalocerâmico sob uma condição definida de carga. Ainda segundo os autores, seria improvável que este teste ou qualquer tipo semelhante pudesse dar uma referência da medida absoluta da adesão da cerâmica ao metal, exceto em casos onde o par cerâmica/metal possua coeficientes de expansão térmica tão idênticos que a interface seja completamente livre de tensões. Foram confeccionados corpos de prova com três diferentes tipos de ligas: Ni-Cr (Wiron), Co-Cr e liga de ouro, a fim de se obter uma comparação direta entre a resistência de união da liga de ouro com as ligas de $\mathrm{Ni}-\mathrm{Cr}$ e $\mathrm{Co}-\mathrm{Cr}$. Com a liga de $\mathrm{Ni}-\mathrm{Cr}$, os testes foram realizados em condições de pressão atmosférica negativa (vácuo), para eliminar a formação do óxido de cromo, levando em consideração que este componente quando presente na interface, reduz a resistência de união. Os autores confirmaram que a união liga de ouro/cerâmica foi satisfatória, devido ao fato de que ocorriam fraturas coesivas na cerâmica antes mesmo de que ocorressem na interface. Já com as ligas de metal não-nobre a fratura ocorria na interface metalocerâmica. Com base nos resultados, os autores concluíram que o óxido de cromo pode reduzir o coeficiente de expansão térmica da cerâmica a um nível tão baixo que passa a se tornar inaceitável; que a formação do óxido de cromo, quando suprimida pelo controle da atmosfera, ainda acontece provavelmente pela redução química de alguns produtos presentes na cerâmica; e que em virtude da ocorrência da formação do óxido de cromo a união metalocerâmica torna-se duvidosa. Tal fato põe em questão a utilização desses 
metais nas restaurações metalocerâmicas, já que nas ligas alternativas o alto índice de cromo é essencial para que a resistência à corrosão seja mantida.

$\mathrm{Na}$ década de 70, uma época em que o custo do ouro começou a aumentar e a preocupar aqueles que o utilizavam como elemento principal para as ligas odontológicas, marcou o início do incremento das pesquisas sobre as ligas não-áureas ou seminobres para restaurações dentais. É provável que as primeiras substituições tenham ocorrido justamente para os trabalhos com cerâmica aplicada sobre ligas metálicas, devido ao custo das ligas à base de ouro para esse fim, que foi sempre mais alto do que o das ligas áuricas para outros tipos de restaurações. Em 1973, MOFFA et al. ${ }^{43}$ estudaram as propriedades físicas destas ligas, dentre elas a resistência de união metalocerâmica, utilizando o método descrito por ANTHONY et al. $^{1}$ para os testes de resistência ao cisalhamento. As avaliações foram feitas utilizando-se liga nova e reutilizada, adicionada de 25 a 50\% de liga nova. A cerâmica utilizada foi a Ceramco. Os resultados de resistência de união ao cisalhamento foram, segundo os autores, significantemente altos e a reutilização não provocou efeitos deletérios na resistência de união às ligas.

MOFFA; JENKINS ${ }^{42}$, em 1974, utilizaram várias ligas de metais nobres e não-nobres e avaliaram a resistência de união metalocerâmica com estes metais. Durante os testes com ligas não-nobres, foi observado um aumento significativo da resistência frente às ligas de metais nobres. Segundo os autores, este aumento não existe e são necessários mais testes para a comprovação ou não do mesmo. 
SIMONPAOLp5, em 1975, define as cerâmicas como vidros, transparentes ou opacos, que recobrem por fusão os metais com um propósito estético ou funcional. A cerâmica ideal deve reunir um conjunto de qualidades como adesão ao metal sobre o qual é fundida e conservação dessa aderência; resistência aos choques e às deformações das peças às quais está aplicada; resistência a agentes físicos e químicos; tolerância dos tecidos orais; capacidade de reprodução de detalhes anatômicos; técnica de aplicação simples; estética agradável e preço acessível. Já para as estruturas metálicas que receberão cerâmica, sua resistência está em função de suas características mecânicas e todos os estudos feitos com base nessas características mostram que dentre todas as propriedades, a de elasticidade é a mais importante para uma liga destinada à confecção de restaurações metalocerâmicas. Deste modo, uma infra-estrutura metalocerâmica deve ter um bom comportamento durante todas as deformações, do contrário, elas acarretariam inevitavelmente uma fratura da cerâmica que não sofre deformação. Para esse autor, as ligas de $\mathrm{Ni}-\mathrm{Cr}$ possuem módulo de elasticidade duas vezes maior do que as ligas de ouro e isso garante maior resistência às solicitações funcionais.

Também em 1975, LANDEZ ${ }^{32}$ preconizava a oxidação prévia à aplicação da cerâmica pois acreditava que esse processo promovia uma reação química mais efetiva entre o metal e a cerâmica. O processo de oxidação prévia consiste no aquecimento da peça metálica a uma temperatura inicial de $750^{\circ} \mathrm{C}$ e uma final de $1040^{\circ} \mathrm{C}$, com velocidade de aquecimento de $40^{\circ} \mathrm{C} /$ minuto, mantendo a temperatura final por 30 segundos, sob vácuo. Terminado o processo, procedia-se a 
uma inspeção visual da infra-estrutura onde a coloração indicava o sucesso da oxidação se a peça tivesse uma coloração azul metálica. Já se apresentasse uma coloração marrom, a temperatura final havia sido muito alta e no caso de uma coloração violeta, a temperatura havia sido muito baixa. No caso das peças onde a oxidação não foi efetiva, repetia-se a usinagem e a oxidação. O autor salientava ainda que previamente à aplicação da cerâmica, a infra-estrutura deveria ser jateada com pó de zircônio para texturização, sendo limpa em água destilada em ebulição por dez minutos. A aplicação do opaco foi realizada em duas etapas: uma primeira camada para promover a união e uma segunda para mascarar o metal.

A natureza das forças de união entre metal e cerâmica não são de fácil compreensão e, em 1975, MCLEAN ${ }^{41}$ explica acessivelmente os processos que ocorrem entre a cerâmica e o metal, permitindo um entendimento dos fenômenos. Assim, a retenção é dependente da geometria da infra-estrutura metálica e da correta combinação das expansões térmicas, tanto do metal quanto da cerâmica. Durante o ciclo de queima, a cerâmica não se torna fluida ou fundida, exceto em uma película de $25 \mu \mathrm{m}$ de glaze que aparece na superfície em temperaturas de glazeamento. O resultado disto é um efeito restritivo da cerâmica sobre a liga de ouro que está circundando. No resfriamento, a liga contrai-se mais rápido que a cerâmica, numa tentativa de retornar às suas dimensões originais e porque sua expansão é maior do que a da cerâmica. O ouro, numa tentativa de contrair-se mais rapidamente do que a cerâmica, ficará sob tensão e a cerâmica sob compressão. Os sistemas metalocerâmicos são idealizados com pequena diferença no coeficiente de expansão térmica entre metal e cerâmica, sendo a expansão desta, ligeiramente 
menor do que a da liga metálica, o que faz com que a estrutura metálica fique sujeita a uma leva compressão. Para as ligas de $\mathrm{Ni}-\mathrm{Cr}$ os óxidos que se combinam com a cerâmica podem reduzir o coeficiente de expansão em até $50 \%$, com o perigo de ocorrer um alto grau de tensão na união. Em compensação, a oxidação da liga de metais básicos pode ser suprimida pelo controle da atmosfera. Pela redução que ocorre na prática, enquanto a cerâmica sofre a maturação, a interface de união é eficazmente protegida da atmosfera do forno. Qualquer reação seguinte seria então independente do potencial de oxidação dessa atmosfera. $\mathrm{O}$ autor conclui que os sistemas futuros deveriam ter coeficiente de expansão dos óxidos similares ao da liga e da cerâmica opaca, além de boa adesão à superfície da liga, não reagir com a cerâmica e caso aconteça essa reação, não deve interferir com as propriedades desejadas da cerâmica que são resistência, cor e estabilidade.

Mesmo após 20 anos de introdução do sistema metalocerâmico, muitas falhas ainda ocorriam. Esse fato levou WARPHEA; GOODKIND ${ }^{64}$, em 1976, a avaliarem algumas variações nas estruturas metálicas e na confecção de cerâmica em modelos clínicos a fim de minimizar os fatores que influem nas fraturas de restaurações metalocerâmicas. Quarenta e quatro coroas metalocerâmicas foram confeccionadas, tendo como variáveis a utilização ou não de agentes de união, usinagem do metal com diferentes graus de abrasividade e três desenhos de estrutura metálica. As conclusões que os autores chegaram foi que o desenho das estruturas metálicas tem um papel significante na resistência à fratura, isto é, a presença de ângulos agudos pode gerar forças de tensão na cerâmica e ocasionar sua ruptura; os agentes condicionadores de metal não diminuem o risco a fratura, 
mesmo quando aplicado corretamente, inclusive diminuem a resistência quando aplicados em espessura inadequada sobre metal não oxidado; a geometria da infraestrutura e a manipulação adequada dos materiais durante a confecção das restaurações são fatores importantes para o sucesso dessas restaurações, mais que o próprio processo de união metalocerâmica.

ROOT; FINDLEY ${ }^{51}$, ainda em 1976, utilizaram o processo de oxidação em ligas áureas, observaram a importância da dissolução do óxido na cerâmica, quando $œ$ atinge a temperatura de fusão e concluíram que superfícies uniformes propiciam maior capacidade de umedecimento do metal pela cerâmica, promovendo as forças de ligação de Van der Walls, resultando em um aumento da retenção mecânica.

LUBOVICH; GOODKIND ${ }^{36}$, em 1977, relatam que existiram muitas alterações nos sistemas metalocerâmicos, principalmente com a introdução e utilização de ligas não-áureas. Um dos pontos de maior controvérsia tem sido a resistência de união desses materiais. Os autores procuraram determinar a resistência ao cisalhamento quando comparada com metais preciosos. Para isso, utilizaram o método proposto por SHELL; NIELSEN ${ }^{54}$ modificado por ANTHONY et al. ${ }^{1}$. O comentário feito sobre os resultados obtidos foi o de que as ligas não-nobres ou produzem resistência muito menor ou muito maior do que as ligas nobres tradicionais. Os autores ressaltam a necessidade de cuidado na escolha do sistema metalocerâmico e consideraram este tipo de teste como um método seguro, confiável e reprodutível. 
RYLEP ${ }^{50}$, em 1977, comenta em seu artigo sobre união metalocerâmica, que uma liga deve permitir ser "molhada" pela cerâmica opaca, proporcionar adesão adequada e ser termicamente compatível com o material cerâmico. Explica ainda que os estudos científicos podem informar sobre as características físico-químicas ideais que as substâncias devem possuir, mas não podem explicar ao clínico quais das muitas ligas disponíveis devem ser escolhidas para os trabalhos. Isto se deve ao fato de que existem tensões funcionais e parafuncionais na boca, que são diferentes para cada paciente e difíceis de serem padronizadas. Somado a isto, não existe um método universalmente aceito para avaliação da resistência de união metalocerâmica e os resultados conflitantes de valores para essas observações, têm causado certa confusão.

CAPUTO; DUNN; REISBICK ${ }^{13}$, em 1977, propuseram um teste de resistência à flexão para determinar a resistência de união metalocerâmica. Os autores afirmaram que o teste proposto por LAVINE; CUSTER ${ }^{35}$ tinha o inconveniente de que ao se fraturar a cerâmica, ocorriam falhas por tração da cerâmica mais do que de união. Para isto, ao invés de se utilizar uma camada contínua de cerâmica sobre a lâmina de metal, somente uma porção foi recoberta no meio da lâmina e esta foi virada para baixo, com a força incidindo em sua porção superior. A conclusão a que os autores chegaram foi que o aumento da oxidação nas ligas áuricas não aumenta a resistência de união e que para as ligas não-nobres a oxidação por dez minutos, com ou sem jatos de material abrasivo, produziu as maiores resistências de união para estas ligas. 
ANUSAVICE; HORNER; FAIRHURST ${ }^{4}$, também em 1977, analisaram a interface metalocerâmica com o objetivo de melhor entender o que ocorre nessa região. Por meio de um microscópio de varredura com um espectômetro de dispersão de energia de raios- $x$, procuraram verificar a origem dos elementos que se concentram na interface formada pela cerâmica e a liga de metais nobres, além de caracterizar a morfologia produzida na oxidação do metal e a interação metalocerâmica e avaliar os efeitos da oxidação do metal, tempo de queima e exposição da superfície ao ácido no comportamento de difusão dos principais elementos. Os resultados confirmaram a hipótese inicial dos autores, da ocorrência de concentração de Sn próximo à interface, utilizando ligas que continham inicialmente concentrações moderadas a baixas de $\mathrm{Sn}$ com as cerâmicas que continham concentrações mais altas de $\mathrm{Sn}$ do que as ligas. O que parece então é que os íons que se acumulam na interface têm origem a partir da cerâmica. A zona de aderência pode ser afetada pela interação dos íons $\mathrm{Si}$ e $\mathrm{Sn}$ na forma de $\mathrm{SnO}_{2}$ SiO ou uma formação composta de Sn-Si-O, quando a concentração de Sn atinge um nível suficiente na câmara de queima, reação de óxido-redução entre a cerâmica e a camada de óxido metálico e a dissolução química do óxido metálico e do metal pela cerâmica, pode ser esperado para a estrutura característica da zona de aderência. Os autores concluem que essas interações realmente têm um efeito importante sobre a interface metalocerâmica mas que um teste mais refinado deveria ser desenvolvido.

Para LACY ${ }^{31}$, em 1977, o ponto mais importante quando se trata de trabalho laboratorial e clínico é sem sombra de dúvidas, a união química entre metal 
e cerâmica. Segundo ele, a união acontece devido à transferência direta de elétrons entre os átomos de oxigênio da cerâmica com os elementos oxidantes da liga. Durante a oxidação, principalmente nas ligas nobres como Au-Pt-Pd, ocorre a formação de uma camada de óxido metálico, sem a qual a cerâmica destaca-se da liga, sem evidenciar a aderência. Já nas ligas não-nobres, como por exemplo as de $\mathrm{Ni}-\mathrm{Cr}$, a oxidação quando feita em excesso diminui a resistência de união, promovendo a fratura da cerâmica.

Continuando seus trabalhos sobre avaliação físico-química da interface metalocerâmica, ANUSAVICE; RINGLE; FAIRHURST ${ }^{5}$ ainda em 1977, determinaram o efeito dos agentes de união, os perfis de difusão dos óxidos na interface e as correlações entre a morfologia da interface com o comportamento da difusão dos óxidos. Segundo os autores, nas ligas de Ni-Cr podem existir diversos produtos de reação na interface, e sua formação vai depender da cinética da óxidoredução e da difusão dos íons metálicos que se ligarão com os elementos cerâmicos. O estudo mostrou que os óxidos tão importantes para a ligação metalocerâmica nas ligas de $\mathrm{Ni}-\mathrm{Cr}$ podem existir em conformações simples como o $\mathrm{Cr}_{2} \mathrm{O}_{3}$ ou NiO, ou em formas mais complexas como $\mathrm{TiO}_{-}-\mathrm{Cr}_{2} \mathrm{O}_{3}$.

No mesmo ano, WEISS ${ }^{66}$ ressalta a importância do jateamento superficial das estruturas metálicas no sentido de favorecer o "molhamento" da superfície pela camada de opaco, promovendo um íntimo contato entre a cerâmica e o metal, além do fato de os sulcos e crateras formados pelo jateamento restringirem a tensão gerada na interface, compensando possíveis diferenças nos coeficientes de 
expansão térmica entre os dois materiais. O estudo avaliou ainda a oxidação prévia, por meio de exames da superfície da liga após cinco minutos sob vácuo a uma temperatura de $1010^{\circ} \mathrm{C}$. Uma superfície azulada indica que a camada de óxidos tem uma espessura adequada, enquanto uma superfície amarelada, marrom ou preta indica a presença de contaminantes ou uma camada de óxidos muito espessa. Dependendo da extensão e profundidade das manchas, estas podem ser removidas com jatos abrasivos, caso contrário, as estruturas metálicas devem ser descartadas.

STEIN; KUWATA ${ }^{59}$, em 1977, explicam que a teoria físico-química da união metalocerâmica baseia-se na troca de elétrons entre os elementos oxidáveis da cerâmica com traços de elementos oxidáveis na superfície metálica, sendo o óxido da liga produzido após a desgaseificação, em uma temperatura maior do que a de cocção da cerâmica. Segundo os autores, mais óxido será formado durante a cocção da cerâmica uma vez que existem elementos oxidáveis nas massas cerâmicas. Portanto, a camada de óxidos formada pela oxidação prévia deveria ser abolida, sob pena de durante a cocção, haver uma formação excessiva de óxidos que poderia prejudicar a união metalocerâmica. Mais estudos seriam necessários para que os fabricantes pudessem incorporar os elementos óxidos aderentes nas ligas. Os autores alertam para as distorções que o processo de oxidação pode induzir nas infra-estruturas metálicas.

Segundo CASCONE; MASSIMO; TUCILLO ${ }^{16}$, em 1978, é necessária a presença de óxidos na superfície metálica para que haja a formação de ligações químicas entre o metal e a cerâmica. Com base nesta filosofia, os autores realizaram 
um estudo para avaliar a natureza dos óxidos formados em determinadas ligas estudadas sob certas condições. Foi utilizada a difração de raios-x para a determinação do tipo de óxido formado e empiricamente, avaliou-se a taxa de oxidação. Além disso, utilizourse a microscopia óptica como meio para examinar alterações sub-superficiais como a oxidação interna. Os modelos teóricos de Wagner foram utilizados como padrão para comparações e interpretação dos resultados. As ligas de Au-Pt e Au-Pt-Pd seguiram rigorosamente os modelos de oxidação seletiva. Já as ligas de Au-Pd e Au-Pd-Ag seguiram o modelo mas algumas complicações foram introduzidas devidas à oxidação interna. A solubilidade da liga ao $\mathrm{O}_{2}$ foi considerada como significante no mecanismo de oxidação.

CARTER; AL-MUDAFAR; SORENSEN ${ }^{14}$, em 1979, avaliaram a resistência de união metalocerâmica utilizando um novo tipo de teste, o qual baseava-se em forças de torção. Foram observados os efeitos da rugosidade superficial e dos agentes de oxidação na união de uma liga de Ni-Cr com a cerâmica Justi-Pe. Foi realizado um tratamento nas ligas que consistiu na oxidação prévia por 5 e 10 minutos, acabamento com lixa 400 e jatos de óxido de alumínio. Em alguns corpos de prova foi aplicado agente de união. Procedeutse à aplicação da cerâmica desde as camadas de opaco até as de corpo sob as mesmas temperaturas e tempos de cocção. Como conclusão os autores explicam que os óxidos superficiais e os jatos abrasivos favorecem a união; que os corpos de prova lisos, sem agente de união e com a camada de óxidos removida não desenvolvem óxidos suficientes para promover uma boa união; que os agentes de união promovem uma formação adicional de óxidos, favorecendo indiretamente a união; e que os agentes de união 
podem estar envolvidos diretamente na distribuição da tensão residual na interface metalocerâmica.

Desde que SHELL; NIELSEN ${ }^{54}$ afirmaram que uma superfície lisa e uniforme aumenta a capacidade da cerâmica "molhar" o metal, muitos estudo vêm sendo conduzidos para se avaliar a textura ideal da superfície. CARPENTER; GOODKIND ${ }^{15}$, em 1979, utilizando dois tipos de testes conhecidos, um deles foi o de flexão por dobramento proposto por CAPUTO $^{13}$ e o outro o de cisalhamento proposto por SHELL; NIELSEN ${ }^{54}$. Por meio da utilização de um rugosímetro, a qualidade de rugosidades superficiais foi classificada em lisa, média e áspera; além disso foi observada a área e os ângulos reentrantes. Quando se utilizou o primeiro teste, não houve diferença significante na resistência de união entre os três tipos de superfície, tanto para ligas áureas como para ligas de Ni-Cr. Para o segundo teste, houve diferença significante nas ligas de Ni-Cr e não para as áureas. Segundo os autores, essas diferenças podem ser devidas à quantidade e possivelmente à espessura da camada de óxidos formada na superfície. A técnica de texturização superficial possui as vantagens de aumentar a capacidade da cerâmica "molhar" o substrato formado pelo metal, de conferir uma resistência de união adicional pelo imbricamento mecânico sob compressão, e de aumentar a área de superfície para a união química com a cerâmica. Porém, existem desvantagens para essa diferença de textura que seriam: a rugosidade excessiva poderia resultar em tensões na interface, ângulos reentrantes aprofundados e abruptos poderiam dificultar a completa "molhabilidade" e ainda resultar em aprisionamento de ar ou surgimento de espaços vazios na interface. 
Em 1980, MALHOTRA; MAICKEL ${ }^{40}$ modificaram o teste proposto por SHELL; NIELSEN ${ }^{54}$, relatando que este teste poderia produzir uma adesão entre o gesso e a cerâmica, resultando em valores mais altos do que seriam realmente. Para contornar este fator de erro, os autores realizaram os testes de duas maneiras: com corpos de prova sem isolamento e com corpos de prova isolados por meio da aplicação de cera. A modificação realizada no teste, proporcionou resultados confiáveis e se demonstrou um excelente método para comparação da resistência de união de sistemas metalocerâmicos. Os autores concluíram que o teste com cargas de compressão é mais eficiente que o com cargas de tração. Eliminando-se a interferência da adesão do gesso com o metal por meio do isolamento com cera, eliminaram-se valores ocasionados por essa interferência de aproximadamente 4500psi a 6000psi. Além disso, quando comparourse o sistema Ceramco com a liga Ceramco gold, obtiveram-se valores de resistência de 12000psi nos testes de compressão e 9700psi nos testes de tração.

A medida da resistência de união tem tido tanta ou mais atenção do que qualquer outra propriedade da cerâmica aplicada sobre o metal. Segundo CHONG; BEECH; $\mathrm{CHEM}^{19}$, em 1980, os testes até agora desenvolvidos apesar de adequados para este fim, são muito complexos ou então possuem um desenho onde as forças interferem ou certas condições estão presentes podendo afetar os resultados de resistência de união. Segundo os autores é quase impossível desenvolver um teste que leve em conta todas as variáveis encontradas em condições práticas. Um teste completo deveria avaliar isoladamente a resistência de união por meio de forças de cisalhamento, ter simples execução, ter um número 
mínimo de variáveis, ter corpos de prova de simples e barata confecção, garantir a união de interface com único tipo de adesão e permitir que os resultados fossem avaliados quantitativamente. Uma publicação da "American Dental Association" (A.D.A.), o "Dentis's Desk Reference" de 1981, trata das características principais da união metalocerâmica, que são: união por meio de ligações químicas na interface; união pelas forças de Van der Walls, para qual é imprescindível o "molhamento" da superfície da liga pela cerâmica; e a união mecânica, onde há a penetração da cerâmica nas irregularidades da superfície metálica. Ainda segundo esta publicação, existem outros fatores que devem ser considerados como os processos de oxidação prévia, tempo e temperatura de queima, concentração inicial de elementos ativos de difusão tanto na cerâmica como no metal, comportamento da óxido-redução entre o metal e a cerâmica, índice do ponto de solução e saturação do óxido do metal na cerâmica e a atmosfera do forno.

Em 1981, ÖILO; JOHANSSON; SYVERUD ${ }^{46}$ realizaram uma comparação entre dois testes para avaliação da união metalocerâmica. Para isso utilizaram o teste de SHELL; NIELSEN ${ }^{54}$ e o teste de SCHMITZ; SCHULMEYER ${ }^{46}$, semelhante ao teste proposto por $\mathrm{CHONG}$; $\mathrm{BEECH}$; $\mathrm{CHEM}^{19}$, com a diferença de que ao invés da cerâmica ser aplicada em forma de cilindro, esta foi aplicada em forma de cubo, aderida à superfície do metal e na superfície em que se executa a pressão, uma camada de resina epóxica faz com que a pressão não atue diretamente sobre a cerâmica. Utilizaram-se para este estudo, quatro ligas sobre as quais foi aplicada a cerâmica Ceramco. Foram encontradas diferenças significantes quando da realização do primeiro teste para as ligas, e o segundo teste teve uma 
redução de 10 a $20 \%$ em relação ao anterior. Os autores chegaram a conclusão de que a geometria dos espécimes e os requisitos para um acurado e complexo trabalho com um sistema preciso de carga, parece tornar os testes utilizados impróprios para avaliação da resistência de união entre metal e cerâmica.

Ainda em 1981, CHIODI NETO ${ }^{18}$ utilizou um teste derivado daquele proposto por SHELL; NIELSEN ${ }^{54}$, onde eram utilizadas tensões de cisalhamento. $\mathrm{O}$ autor empregou uma nova metodologia para avaliar a resistência de união metalocerâmica aplicada em uma liga de Ni-Cr (Unibond) em uma área soldada com solda específica para a referida liga, e a influência na adesão da cerâmica quando se aplicava cerâmica de corpo sobre opaco. Os corpos de prova eram cilíndricos e recebiam cerâmica do sistema Vita VMK, aplicada em forma de semicírculo ao redor do corpo de padrão metálico. O autor concluiu que os opacos quando aplicados sobre solda apresentaram maior resistência de união; que quando a camada de corpo foi aplicada sobre o opaco, a resistência também foi aumentada; que a aplicação da camada de corpo sobre a de opaco conferiu maior resistência e a fratura ocorreu sempre na interface quando a força era aplicada sobre a cerâmica; e que os resultados demonstraram que a união com o opaco do sistema VMK apresentou sempre maior resistência do que opaco + agente de união.

FERNANDES NETO22, em 1982, realizou testes para avaliar a influência da reutilização de ligas de Ni-Cr com a aplicação de dois tipos de opaco do sistema VMK-68 em diversas condições: 100\% de liga nova, 50\% de liga refundida e $100 \%$ de liga refundida. Para realização dos testes, o autor utilizou a 
metodologia descrita por $\mathrm{CHIODI} \mathrm{NETO}^{18}$, e obteve resultados que demonstraram que a liga 100\% refundida apresentou maior resistência para os dois tipos de opaco; que o opaco Paint-on 68 aplicado sobre a liga 50\% refundida demonstrou a menor resistência; que para o opaco Paint-on 88 a 50\% de liga refundida a resistência foi maior do que para a liga 100\% nova; e que comparando os dois tipos de opaco, o Paint-on 68 apresentou resultados melhores que o Paint-on 88.

LANZA $^{33}$, em 1982, utilizando a metodologia descrita por CHIODI $\mathrm{NETO}^{18}$, realizaram testes de cisalhamento empregando duas ligas à base de $\mathrm{Ni}-\mathrm{Cr}$ (Unibond e Durabond) e dois opacos do sistema Vita VMK (Paint-on 68 e Paint-on 88). Previamente à aplicação da cerâmica realizou-se a oxidação prévia para as duas ligas, seguida de jateamento com óxido de alumínio e limpeza em água destilada e ultra-som. A conclusão foi que a oxidação prévia diminuiu a resistência de união; não houve diferenças entre os dois opacos sem oxidação para a liga Durabond; a liga Unibond apresentou resultados superiores com o opaco Paint-on 68 sem oxidação; e a liga Durabond foi superior à liga Unibond.

No mesmo ano, MCLEAN ${ }^{18}$ estudou a adição de metais como o berílio, alumínio, nióbio e manganês às ligas de $\mathrm{Ni}-\mathrm{Cr}$ para controlar a formação de óxidos de cromo. Porém a adição destes metais tende a criar uma camada fina de óxidos que pode interferir com a união química. Segundo o autor, a camada de óxidos não deve se difundir em direção a cerâmica, permanecendo estável. Para que isso aconteça, deve-se aplicar uma fina camada de opaco $(100 \mu \mathrm{m})$ para que esta "molhe" inteiramente a superfície metálica e em seguida queimá-la $20^{\circ} \mathrm{C}$ acima da 
temperatura indicada. A seguir, aplica-se a segunda camada de opaco para mascarar o metal, e sua queima é realizada em temperaturas normais indicadas.

Em 1983, CASCONE $^{16}$ relata que a substituição do Cobre pela Prata nas ligas de Paládio introduziu o fenômeno da oxidação neste tipo de liga. Com base neste pensamento, realizou um estudo para identificar os produtos de oxidação formados, sua cinética e seus efeitos na aderência da cerâmica. As ligas utilizadas foram as de Pd-Cu-Ga e Pd-Cu-In. A cinética da oxidação do paládio puro também foi estudada. Para a avaliação, o autor utilizou uma análise termogravimétrica, difração de raios-x e metalografia óptica. Foram observadas oxidação interna e externa em todas as ligas estudadas. A formação básica externa da liga de Pd-Cu$\mathrm{Ga}$ consiste inicialmente de $\mathrm{CuO}$ e $\mathrm{Ga}_{2} \mathrm{O}_{3}$. Acima de $600^{\circ} \mathrm{C}$ forma-se $\mathrm{CuGa}_{2} \mathrm{O}_{4}$. A formação deste tipo de óxido resulta em baixa aderência da cerâmica devido à baixa solubilidade do óxido na cerâmica opaca. Para as ligas de Pd-Cu-In, a configuração inicial conta com a presença de $\mathrm{CuO}$ e $\ln _{2} \mathrm{O}_{3}$, mas o $\mathrm{Cu}_{2} \ln _{3} \mathrm{O}_{5}$ não se forma tão rapidamente como o $\mathrm{CuGa}_{2} \mathrm{O}_{4}$, permitindo que o $\mathrm{CuO}$ de dissocie em $\mathrm{Cu}_{2} \mathrm{O}$ e $\mathrm{O}_{2}$. Segundo o autor, a liberação de $\mathrm{O}_{2}$ resulta em uma camada de opaco porosa e com baixa resistência de união.

MACKERT; RINGLE; FAIRHURST ${ }^{37}$, em 1983, analisaram o comportamento de uma liga de Pd-Ag durante os ciclos de aquecimento para aplicação da cerâmica. Para isto, utilizaram um lingote com dimensões $5 \mathrm{~mm}-10 \mathrm{~mm}$ $30 \mathrm{~mm}$ obtido em forno de indução. O lingote passou por um processo de usinagem e em seguida foi tratado termicamente seguindo a seguinte escala: o corpo de prova 
era colocado no forno para aplicação de cerâmica à temperatura inicial de $650^{\circ} \mathrm{C}$. A pressão era então reduzida para 0,1 atm e elevava-se a temperatura em $56^{\circ} \mathrm{C}$ por minuto até a temperatura máxima para cada observação. As temperaturas máximas foram $750^{\circ} \mathrm{C}, 850^{\circ} \mathrm{C}, 950^{\circ} \mathrm{C}, 1010^{\circ} \mathrm{C}$ e $1010^{\circ} \mathrm{C}$ com espera de cinco minutos. Após cada ciclo térmico, a superfície metálica foi observada em microscopia eletrônica de varredura e a quantidade e qualidade dos "nódulos" presentes nessa superfície eram avaliadas. Segundo os autores, os nódulos de Pd-Ag que se formam na superfície da liga durante a pré-oxidação são devidos a uma espécie de compressão hidrostática induzida pela oxidação interna de elementos como o estanho e o índio. A superfície da liga é formada por Pd-Ag na forma metálica e a oxidação do estanho e do índio, ocorrem internamente. Ainda segundo os autores, a cerâmica é retida na superfície desse tipo de liga primariamente por interposição mecânica com os nódulos de Pd-Ag. O problema da descoloração pode ser explicado pela vaporização da prata das superfícies destas ligas.

MACKERT et al. ${ }^{38}$, em 1984, descrevem um método para avaliação da aderência de um óxido ao seu substrato metálico até um valor máximo de 40MPa. Foram utilizadas nove diferentes ligas de $\mathrm{Ni}-\mathrm{Cr}$ e dez corpos de prova de formato achatado foram confeccionados para cada tipo de liga. Os corpos de prova foram "colados" entre dois cilindros de alumínio com um adesivo poderoso à base de cianoacrilato e submetidos à carga até que ocorresse a separação entre a camada de óxido e a superfície metálica. Com base nos resultados foram encontradas diferenças estatisticamente significantes entre os valores de aderência dos óxidos das diferentes ligas metalocerâmicas. Para cinco tipos de ligas, os valores de 
aderência encontrados foram maiores do que os relatos encontrados na literatura para a resistência coesiva da camada de cerâmica opaca, indicando que esses óxidos possuem aderência suficiente para atuar como uma zona de transição entre a cerâmica e o metal. Em adição a isto, uma correspondência foi encontrada entre a qualidade da união metalocerâmica e o tipo de óxido de determinada liga. Segundo os autores, os resultados derrubam alguns conceitos e enfatizam a necessidade da presença dos óxidos para uma perfeita união.

HERØ; SYVERUD ${ }^{26}$, em 1985, realizaram um experimento com a finalidade de avaliar a qualidade da interface metalocerâmica de três ligas à base de $\mathrm{Pd}(\mathrm{PdCuGa}, \mathrm{PdCoGa}, \mathrm{PdAgSn})$. As ligas foram incluídas em revestimentos à base de carbono com a finalidade de introduzir-se pequenos e diferentes níveis de contaminação por carbono nas ligas. Como controle foi utilizado um revestimento à base de cerâmica e os resultados foram avaliados a partir de testes de flexão em corpos de prova com metal e cerâmica, além da análise das superfícies da interface em microscopia eletrônica. Sabe-se que o paládio tem uma "habilidade" em dissolver o carbono e o hidrogênio particularmente durante o intervalo de fusão. A utilização de revestimentos ricos em carbono ou grafite, bem como uma chama redutora durante a fundição da liga são prováveis fontes de impurezas de carbono. A introdução de carbono em ligas de Pd provoca um aumento das porosidades e bolhas na interface metalocerâmica, provavelmente devido ao fato de que o carbono difunde-se facilmente pelo Pd durante sua fundição. Além disso, durante a queima da cerâmica, o carbono reage com o oxigênio causando o aparecimento de monóxido de carbono (CO) aprisionado em bolhas na região da interface. Esta seria 
uma explicação plausível para os baixos valores de resistência de união metalocerâmica em ligas ricas em carbono. Segundo os autores, as ligas de PdCuGa e PdCoGa tiveram até mesmo uma redução na maleabilidade e sofreram distorções quando incluídas em revestimentos à base de carbono ou grafite. Em contraste, a liga de PdAgSn não foi muito afetada pela inclusão em revestimentos ricos em carbono.

O efeito dos agentes de união sobre a superfície metálica foi estudado por BOWERS; VERMILYEA; GRISWOLD ${ }^{10}$, em 1985, por meio da utilização de três condicionadores de metal aplicados sobre quatro ligas (Biocast, Rexillium III, Unibond e Biobond). Os autores concluíram que os agentes de união funcionam somente como uma barreira de contaminantes, absorvendo o excesso de óxido formado na superfície do metal durante a cocção da cerâmica. Presume-se que os agentes de união tenham importância na estética, limitando alterações de coloração durante os ciclos de queima. A conclusão foi que o sucesso da união metalocerâmica deve-se ao desenvolvimento de uma fina camada de óxido aderente sobre o substrato metálico, formando uma camada monomolecular (metal+cerâmica).

Ainda em 1985, segundo YAMAMOTO ${ }^{68}$, se o conteúdo de uma liga for rico em metais básicos e esta for aquecida a altas temperaturas por longos períodos de tempo, ocorrerá a formação de uma espessa camada de óxidos. Devido a este fator, a resistência de união varia significativamente dependendo do tipo de liga e do 
tratamento de superfície. Isto significa que o pré-tratamento da liga deve ser realizado de acordo com as características de cada liga.

Em 1985, ANUSAVICE ${ }^{2}$ analisa as vantagens e desvantagens das ligas consideradas nobres, isto é, que contenham grandes quantidades de metais nobres tais como o ouro, platina, paládio, ródio, rutênio, irídio e ósmio. Particularmente às ligas de $\mathrm{Pd}-\mathrm{Ag}$, o autor cita que foram introduzidas no mercado por volta de 1974 como uma alternativa para as ligas de ouro cujo preço era muito alto. A composição varia entre 56 a $61 \%$ em peso de $\mathrm{Pd}$ e 28 a $40 \%$ de prata. $\mathrm{O}$ estanho ou o índio podem ser adicionados com a finalidade de aumentar a dureza e promover a formação de óxidos em um nível ótimo que garanta a perfeita aderência da cerâmica. A substituição do ouro pelo paládio provocou um aumento na temperatura de fusão e diminuição do coeficiente de expansão térmica. A adição de prata tem como objetivo a diminuição da temperatura de fusão e aumento no coeficiente de expansão térmica. Devido a esse aumento na quantidade de prata, pode ocorrer um efeito de descoloração por prata ocasionando alteração da coloração da cerâmica, que pode ser evitado por meio da utilização de condicionadores de metal ou agentes mascaradores na cerâmica. Além disso, é de bom senso a utilização de cerâmicas que não sofram alterações por descoloração por prata. Logicamente este efeito só é considerado importante em se tratando de restaurações anteriores que envolvam a estética. A baixa densidade, adicionada com o baixo preço, fazem deste tipo de liga um material muito atrativo como uma alternativa para as ligas áuricas. Algumas ligas deste grupo, principalmente as com reduzido conteúdo de prata (28\%), parecem ser mais facilmente manuseáveis 
quando comparadas com outras ligas nobres. A aderência com a cerâmica é considerada boa na maioria das ligas de Pd-Ag. Existe um estudo demonstrando que estas ligas podem sofrer oxidação interna ao invés de externa. Nesse momento, ocorre a formação de "nódulos" que podem prejudicar a retenção, mas sem grande significância clínica.

Os efeitos dos diferentes tratamentos superficiais foram estudados por DAFTARY; DONOVAN²0 em 1986, utilizando três ligas de Ni-Cr e uma liga de ouro. As variáveis no tratamento da superfície foram: a) desgaseificação convencional, b) dupla desgaseificação, por que segundo ANUSAVICE ${ }^{2,3,4}$, há evidências de aumento na formação de óxidos de cromo na superfície da liga, favorecendo a união com o metal, c) ataque ácido dos padrões metálicos após desgaseificação utilizando-se solução com $20 \%$ de ácido nítrico, $75 \%$ de ácido sulfúreo e $5 \%$ de ácido fosfórico por 30 minutos à temperatura de $90^{\circ} \mathrm{C}$, d) queima do opaco a uma temperatura $38^{\circ} \mathrm{C}$ maior do que a recomendada pelo fabricante, que propiciará uma transferência de óxidos entre metal e cerâmica, aumentando a resistência. Os autores concluíram que para a união metalocerâmica ser satisfatória, deve-se atentar para o desenho da infra-estrutura, composição da liga, semelhança nos coeficientes de expansão térmica do metal e da cerâmica, preparação da estrutura metálica e técnica de aplicação da cerâmica.

HAMMAD; GOODKIND; GERBERICH ${ }^{25}$, em 1987, utilizando uma liga de metal precioso (Olimpia) e outra de metal básico (Talladium), aplicaram opaco do sistema Ceramco II e realizaram testes de resistência ao cisalhamento, observando 
três variáveis: efeito da temperatura de cocção, tipo de metal e textura de superfície. Os corpos de prova foram divididos em três grupos: um grupo com ataque eletrolítico após jateamento com óxido de alumínio, outro grupo de metais básicos com jateamento de óxido de alumínio de $25 \mu \mathrm{m}$ e um terceiro grupo de ligas preciosas onde foi realizada desgaseificação e jateamento com óxido de alumínio. Durante a aplicação da cerâmica utilizaram-se duas variáveis: um grupo sofreu cocção em temperaturas normais e outro a $32^{\circ} \mathrm{C}$ acima do indicado pelos fabricantes. Os autores concluíram que nos dois sistemas de ligas utilizadas, houve um aumento na resistência de união nos corpos de prova submetidos à cocção $32^{\circ} \mathrm{C}$ acima da indicada. Além disso, nas ligas jateadas a queimadas $32^{\circ} \mathrm{C}$ acima do indicado, também houve aumento da resistência de união. As ligas básicas jateadas obtiveram maior resistência do que as com ataque eletrolítico e ao contrário, com temperaturas mais elevadas, as ligas básicas com ataque eletrolítico mostraram aumento significante em relação às jateadas.

Em 1988, RESKALLA ${ }^{49}$ utilizou o teste de cisalhamento preconizado por CHIODI NETO ${ }^{18}$ e testou a resistência de união metalocerâmica das ligas Nickron G, Resistal P, Kromalit e uma liga experimental obtendo os seguintes resultados: a) diferença significante entre a liga Resistal $\mathrm{P}$ e a liga experimental, com valores médios de resistência de união de 65,78 kgf para a primeira e 128,66 kgf para a segunda; b) diferença significante entre as ligas Kromalit com 73,96 kgf e 128,66 kgf para a liga experimental. Esses resultados levaram o autor à conclusão de que a resistência foi em ordem decrescente das ligas experimental, Nickron G, Kromalit e Resistal P. Além disso, a vitrificação do opaco na liga experimental não 
apresentou resultados positivos quando comparada com a mesma liga sem vitrificação do opaco.

MACKERT et al. ${ }^{39}$, ainda em 1988, realizaram testes de avaliação da união metalocerâmica e segundo eles, o exame da superfície da fratura é um detalhe importante, mais do que o valor numérico da ruptura. Utilizando sete marcas comerciais de ligas e seguindo as recomendações dos fabricantes, os autores estudaram as superfícies das ligas após a fratura da camada de cerâmica com espectometria de raios-x. Após observação dos resultados, alguns critérios foram considerados importantes para que haja uma união metalocerâmica efetiva: a) formação de camada de óxido na interface; b) o óxido formado deve ser aderente ao metal; c) qualidade do óxido. Alguns tipos de ligas formaram óxidos aderentes e outras formaram óxidos não-aderentes e segundo os autores este é um fator importante na escolha da liga, uma vez que a união entre metal e cerâmica depende da interação dos óxidos da liga e da cerâmica.

VRIJHOEF; VAN DER ZEL ${ }^{61}$, em 1988, realizaram um trabalho com o objetivo de avaliar a influência da pressão e do tempo e temperatura de oxidação prévia, na formação de óxidos em uma liga de AuPdlnGa (52\% Au, 38\% Pd, 8.2\% In, $1.6 \% \mathrm{Ga}$ e $0.2 \%$ de componentes menores como refinadores de grãos). Foi confeccionado um espécime plano com dimensões de corte transversal $25 \mathrm{~mm}$ 8,5mm-1mm. O acabamento foi feito com pedras de óxido de alumínio e em seguida a oxidação prévia foi realizada em forno cerâmico. A atmosfera da oxidação foi vácuo a 0.2atm e 0.01atm respectivamente. O tempo da oxidação variou de um a 
dez minutos, enquanto a temperatura variou entre $940^{\circ} \mathrm{C}$ e $1020^{\circ} \mathrm{C}$. Os óxidos foram removidos por dissolução e raspagem com solução de ácido hidroclorídrico 37\% a uma temperatura de $90^{\circ} \mathrm{C}$. As concentrações dos componentes metálicos foram determinadas por meio de um espectômetro de emissão e expressas em termos de porcentagem atômica. Previamente às avaliações, presumia-se que os óxidos $\ln _{2} \mathrm{O}_{3}$ e $\mathrm{Ga}_{2} \mathrm{O}_{3}$ estariam presentes. Após a análise dos resultados, os autores concluíram que não foram encontrados óxidos de $\mathrm{Pd}$ e que os óxidos $\ln _{2} \mathrm{O}_{3}$ e $\mathrm{Ga}_{2} \mathrm{O}_{3}$ realmente foram detectados. O tempo de oxidação não influenciou a composição da camada de óxidos e uma temperatura mais elevada apenas aumentou levemente a concentração de $\mathrm{Ga}_{2} \mathrm{O}_{3}$. Sob todas as condições o componente que sofreu oxidação preferencialmente foi o Ga.

WATANABE ${ }^{65}$, em 1989, realizou estudos para determinar a morfologia dos óxidos formados em ligas de Ni-Cr com adição ou não de Berílio. Alguns tipos de óxidos, como o $\mathrm{Cr}_{2} \mathrm{O}_{3}$ ou $\mathrm{NiCr}_{2} \mathrm{O}_{4}$ formam-se em ligas sem conteúdo de $\mathrm{Be}$, em camadas de espessura uniforme, prosas e com ligações fracas com a liga. Já nas ligas que contêm $\mathrm{Be}$, o óxido que se forma é somente o $\mathrm{BeO}$, que tem forte ligação com a liga e forma uma camada fina e uniforme. Além disso, os óxidos que se formam quando a cerâmica é aplicada em liga contendo Be, compõem uma camada fina e com ótima adesividade à liga.

BÖNING; WALTER ${ }^{9}$, em 1990, avaliando a estrutura dos grãos, resistência à corrosão e microestrutura da interface de diferentes composições das ligas de Paládio, discutem as propriedades destas ligas e como estas afetam sua 
manipulação técnica. Segundo os autores, a estrutura dos grãos das ligas avaliadas

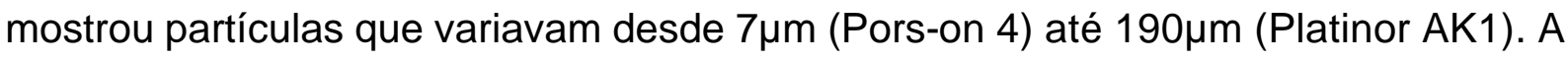
presença de grãos pequenos é devida à incorporação de refinadores de grãos, que são metais com ponto de fusão elevado, como o rutênio e o irídio. Durante a solidificação estes elementos formam uma grande quantidade de núcleos de cristalização. O crescimento dos cristais é interrompido rapidamente e os cristais formados são pequenos. As vantagens de se obter uma liga com estrutura granular pequena, é a qualidade dessa liga em apresentar maior dureza, resistência, elasticidade e maior superfície de contato interna. Para a resistência à corrosão, as ligas de $\mathrm{Pd}$ foram comparadas com as de $\mathrm{Au}-\mathrm{Pt}$, e demonstraram menor resistência do que estas. Além disso, existem muitos agentes oxidantes na saliva e na placa bacteriana, podendo levar a um processo de oxidação das ligas. Porém, mais estudos devem ser realizados para avaliar e mostrar como prevenir a oxidação das ligas de Pd em meio bucal. Já a microestrutura da interface procurou avaliar as diferentes quantidades de grafite presentes nos materiais de revestimento e sua influência na qualidade da interface. Além disso, avaliaram-se duas ligas: Pd-Ag (Pors-on 4) e Pd-Cu-Ga (Degupal). Uma característica do Pd é a alta sensibilidade ao carbono durante a fundição. Porosidades na cerâmica provocadas pela presença de $\mathrm{CO}$ têm sido descritas como devidas à presença de carbono na liga. Devido a essa característica, os revestimentos com grafite são contra-indicados para a fundição de ligas de paládio. Para avaliação da interface, foram confeccionados dez corpos de prova, fundidos em revestimento contendo grafite e em outro sem grafite. Os resultados mostraram que apenas a liga de $\mathrm{Pd}-\mathrm{Cu}-\mathrm{Ga}$ apresentou formação de porosidades na região próxima ao revestimento. Para o revestimento sem grafite 
nenhuma das duas ligas apresentou porosidades. A liga de Pd-Ag apresentou aumentos na concentração superficial de elementos como Sn, In, Ag, Zn e O na interface com diminuição da quantidade de Pd. Internamente, ocorreu o contrário. $\mathrm{Na}$ liga de Pd-Cu-Ga, houve um aumento na concentração superficial de Ga e O. Este aumento na concentração de Ga na interface perece ser crítico no que diz respeito à resistência à corrosão da liga. Porém, os resultados não mostram uma diferença significante nessas concentrações nem em seus efeitos. Os autores concluem que a microestrutura das ligas de paládio difere da microestrutura das ligas de ouro, sendo necessários mais estudos para avaliação da resistência à corrosão. As ligas de paládio devem ser processadas diferentemente das ligas áuricas. Elas exibem uma alta sensibilidade a condições de trabalho adversas. Se são utilizadas de acordo com as instruções dos fabricantes e os técnicos demonstram familiaridade com as mesmas, estas ligas parecem ser uma alternativa aceitável para as ligas de ouro.

WU et al. ${ }^{67}$, em 1991, avaliaram os efeitos do tratamento térmico (oxidação prévia) sobre a resistência de união metalocerâmica com duas ligas de $\mathrm{Ni}$ $\mathrm{Cr}$ com e sem $\mathrm{Be}$, e duas ligas de Co-Cr. Os corpos de prova foram divididos em quatro grupos dependendo do tipo de tratamento térmico recebido: a) temperaturas de $960^{\circ} \mathrm{C}$ e $1010^{\circ} \mathrm{C}$ e tempo determinado pelo fabricante; b) tempos de tratamento de 0 e 10 minutos; c) sob ar ou sob vácuo; d) utilização de agentes de união. Após os testes os autores chegaram à conclusão de que as variações de atmosfera, temperatura e tempo de oxidação não afetaram a resistência de união. Além disso, a utilização de agentes de união aumenta a resistência por meio da difusão de íons de $\mathrm{Al}$, suprimindo os de $\mathrm{Cr}$, formando uma camada de óxido rica e aderente. Os 
agentes de união atuam equilibrando os coeficientes térmicos da cerâmica e do metal, reduzindo as tensões residuais.

Ainda em 1991, BULLEN CABRERA ${ }^{12}$, utilizando a metodologia proposta por $\mathrm{CHIODI} \mathrm{NETO}^{18}$, avaliou a resistência de união entre uma liga de $\mathrm{Ni}-\mathrm{Cr}$ nacional (Durabond MS II) e quatro sistemas cerâmicos (Ceramco, Duceram, Williams e Vita VMK). Os testes foram realizados e com base nos resultados foram avaliados os tipos de oxidação prévia da liga. As conclusões foram: a) O sistema Ceramco teve a maior resistência de união com a liga utilizada; b) O sistema Duceram foi inferior ao Ceramco, mas superior aos sistemas Williams e Vita; c) Os sistemas Williams e Vita não apresentaram diferenças entre si; d) O sistema Vita VMK Paint-on 88 com oxidação prévia demonstrou aumento na resistência da união metalocerâmica quando comparado com a liga sem oxidação prévia.

WAGNER et al. ${ }^{63}$, em 1993, realizaram um estudo para determinar a natureza química da interface metalocerâmica, pois segundo os autores, há muitos estudos sobre o assunto mas poucas evidências físicas para suportá-los. Ainda segundo os autores, existem certos fatores que determinam o sucesso da união metalocerâmica: o estresse residual na interface, a química interfacial e a morfologia interfacial. Para a realização desta pesquisa, foi utilizada uma liga de paládio sob certas variáveis que afetam a adesão: a) pré-cobertura da liga com óxidos de vários elementos; b) oxidação prévia a $982^{\circ} \mathrm{C}$ por cinco minutos; c) cocção da cerâmica sob vácuo; d) criação de rugusidades superficiais. Utilizando testes de cisalhamento por compressão, os autores concluíram que as amostras que receberam cobertura com 
óxido de alumínio mostraram uma melhora de até $46 \%$ na resistência de união quando comparadas com pré-cobertura com óxidos de cobre, manganês ou estanho. A oxidação prévia aumentou a resistência em 152\% devido ao aumento na rugosidade causado pela formação de óxidos. A cocção sob vácuo demonstrou uma redução severa na resistência devido à ausência da formação de óxidos durante a queima. As rugosidades criadas superficialmente propiciaram melhora na resistência de união.

PAPAZOGLOU et al. ${ }^{48}$, em 1993, avaliaram a resistência de união metalocerâmica de quatro ligas de paládio de primeira (PdCuGa) e segunda geração (PdGa), utilizando como controle uma liga de AuPd. Foram confeccionados sete padrões metálicos de cada liga com dimensões $13 \times 13 \times 1 \mathrm{~mm}$, a partir de fundições em revestimento sem carbono aglutinado por fosfato. Após a desinclusão, um dos

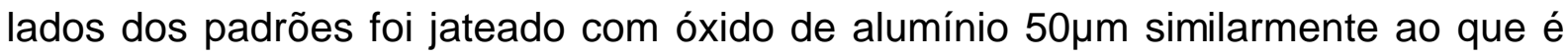
realizado nos laboratórios de prótese. Os procedimentos iniciais de oxidação foram feitos de acordo com as instruções de cada fabricante. Após a oxidação, uma camada de cerâmica opaca foi aplicada em uma área circular de $6 \mathrm{~mm}$ de diâmetro, localizada no centro de cada padrão metálico. Em seguida à aplicação da primeira camada de cerâmica opaca, esta foi jateada e limpa em aparelho de ultra-som por dez minutos. Uma segunda camada de opaco foi aplicada até atingir uma espessura de $0,2 \mathrm{~mm}$. Duas camadas de cerâmica de corpo foram aplicadas até uma espessura de aproximadamente $0,8 \mathrm{~mm}$, que foi confirmada por meio de análise em microscópio óptico. A fratura dos espécimes foi realizada por meio de teste biaxial similar àquele descrito por MACKERT et al. ${ }^{39}$ em 1988. Após a fratura, os espécimes foram 
levados à microscopia eletrônica de varredura com adição de um espectógrafo de dissipação de energia. Todo este aparato técnico serviu para a avaliação da quantidade de cerâmica que permaneceu aderida ao metal, mesmo em nível microscópico, caracterizando uma fratura coesiva. A liga de AuPd mostrou a maior porcentagem de fraturas do tipo coesiva, as ligas de primeira geração ( $\mathrm{PdCuGa}$ ) foram intermediárias e as de segunda geração mostraram a menor porcentagem de área coberta por cerâmica. Segundo os autores, este estudo serviu para demonstrar que a inspeção visual, microscópica de baixa magnificação e técnicas metalográficas padrões, são procedimentos inadequados para avaliação acurada da quantidade de cerâmica aderida ao metal após fratura dos espécimes, o que pode caracterizar uma fratura do tipo coesiva e não adesiva.

SCARANELLO; MUENCH ${ }^{52}$, em 1994, avaliaram a resistência de união metalocerâmicas utilizando ligas de $\mathrm{Ni}-\mathrm{Cr}$ e avaliando a influência de cinco fatores: liga, jateamento, opaco + dentina, cerâmica e vácuo. Utilizando testes de tensão e tração os autores concluíram que todos os fatores foram significantes. Houve diferença na resistência quando avaliourse o tipo de liga, o tipo de cerâmica, uso ou não de vácuo, jateamento e opaco.

DEKON ${ }^{21}$, em 1994, avaliou a resistência de união metalocerâmica de uma liga de Ni-Cr submetida a diferentes tempos de oxidação prévia e após a desgaseificação foi aplicada a cerâmica Vita VMK. O autor utilizou a metodologia proposta por CHIODI NETO ${ }^{18}$, baseada em um teste de cisalhamento, modificada a partir do teste preconizado por SHELL; NIELSEN ${ }^{54}$. Os corpos de prova foram 
divididos em cinco grupos: a) Grupo I - sem oxidação prévia; b) Grupo II - oxidação prévia por um minuto; c) Grupo III - oxidação prévia por três minutos; d) Grupo IV oxidação prévia por cinco minutos; e) Grupo V - oxidação prévia por cinco minutos seguida de jateamento com óxido de alumínio. O autor concluiu que a ausência de oxidação prévia demonstrou os melhores resultados. Os diferentes tempos de oxidação prévia provocaram redução acentuada nos valores obtidos e foram semelhantes entre si. $O$ grupo que sofreu jateamento mostrou resultados semelhantes aos grupos com oxidação prévia sem jateamento.

Em 1996, FERNANDES NETO ${ }^{23}$ avaliou a resistência de união metalocerâmica entre três sistemas cerâmicos: Duceram, Williams e Vita VMK 88 e quatro ligas: Durabond, Litecast $\mathrm{B}$, Resistal $\mathrm{P}$ e uma liga experimental à base de $\mathrm{Cr}$ Co contendo Ti. Com base nos resultados, o autor concluiu que dos sistemas cerâmicos avaliados, o sistema Duceram mostrou-se superior aos sistemas Vita VMK 88 e Williams, respectivamente. Das ligas pesquisadas, a experimental mostrou o melhor desempenho, seguida das ligas Resistal P, Durabond e Litecast B. Das interações testadas, a combinação Resistal P/Duceram apresentou os melhores resultados, seguida por experimental/VMK 88, experimental/Duceram, Durabond/Duceram e Resistal P/VMK 88.

HAMMAD; TALIC ${ }^{24}$, em 1996, revisaram a literatura sobre testes de resistência da união metalocerâmica. Os testes existentes têm sido desenhados e escolhidos pelos pesquisadores com base na natureza das forças que são 
utilizadas, como por exemplo torção, tensão, flexão, cisalhamento e uma combinação de tensão/cisalhamento.

*Testes de cisalhamento - Idealizados por SHELL; NIELSEN ${ }^{54}$ e modificados por muitos outros autores, têm sua metodologia baseada no uso de um fio metálico espesso onde é aplicada a cerâmica e em seguida tenta-se a separação. Com base nos resultados obtidos, os autores concluíram que aproximadamente $1 / 3$ da resistência resulta das forças de van der Walls e $2 / 3$ resultam de interações químicas entre a liga e a cerâmica. Existem vários tipos de testes de cisalhamento:

- Testes de cisalhamento com superfície plana - onde a cerâmica é aplicada sobre uma superfície plana:

- com interface circular - desenvolvido por HAMMAD et al. ${ }^{25}$ em 1987 mas já utilizado anteriormente por CIVJAN et al. ${ }^{39}$ em 1974.

- com interface retangular - idealizado por SCHMITZ ; SCHULME IER ${ }^{24}$ em 1975 e ÖILO et al. $^{46}$ em 1981, considerado mais preciso que o anterior por controlar a espessura da camada de cerâmica e a área da interface. Os testes com superfícies planas são considerados como vantajosos pois distribuem uniformemente as forças de tensão na interface.

- Testes de cisalhamento oblíquo - idealizado por ANUSAVICE $^{3}$ em 1977.

- Testes de cisalhamento cônico - desenvolvidos por SCED; MCLEAN ${ }^{53}$ em 1972. 
*Testes de tensão - KELLY et al. ${ }^{29}$, em 1969, foram muito utilizados para avaliação da aderência da camada de óxidos a ligas cerâmicas. Este tipo de teste tem sido criticado na literatura devido às dificuldades de alinhamento e possibilidade de corte ou ranhura da superfície externa da cerâmica, resultando no possível desenvolvimento de estresses irregularmente distribuídos, ocasionando falhas coesivas na cerâmica.

*Testes de tensão/cisalhamento - WIGHT et al. ${ }^{24}$, em 1977.

*Testes de flexão - LAVINE; CUSTER ${ }^{35}$, em 1966, CAPUTO et al. $^{13}$ em 1976. Utilizados para simular a flexão que acontece no ambiente bucal em próteses metalocerâmicas.

*Testes de torção-CARTER et al. ${ }^{14}$, em 1979.

Segundo os autores, existem muitas variáveis a serem avaliadas. Estas variáveis devem ser minimizadas por meio da padronização dos espécimes e dos métodos para realização dos testes. Os espécimes deveriam ser examinados por meio de um método estatístico balanceado e distribuídos aleatoriamente quando possível. Os testes existentes podem apenas aproximar os valores da resistência de união metalocerâmica pois deveriam levar em conta os coeficientes de expansão térmica dos componentes. A avaliação mais aceitável seria aquela que tivesse menos variáveis e gerasse menores estresses residuais na interface metalocerâmica. Ao mesmo tempo em que os estudos de laboratório têm sido um importante guia para a seleção clínica de materiais, estudos clínicos deveriam ser conduzidos para contribuir com os laboratoriais. 
BATISTA $^{7}$, em 1997, avaliou a resistência de união metalocerâmica, utilizando diferentes sistemas de aplicação de opacos: pasta, convencional e agente de união. Para a confecção dos corpos de prova e realização dos testes de cisalhamento, idealizou uma matriz que padronizava a espessura do metal e da cerâmica dos corpos de prova. Além disso, a mesma matriz podia ser adaptada à maquina de ensaios para a realização dos testes. Os corpos de prova foram confeccionados em liga de $\mathrm{Ni}-\mathrm{Cr}$ (Durabond II MS) e foram divididos em quatro grupos: a) opacos em pasta, b) agente de união/opacos em pasta, c)agente de união/opacos convencionais e d) opacos convencionais.

PAPAZOGLOU; BRANTLEY ${ }^{47}$, em 1998, avaliaram a quantidade de aderência e a resistência de união metalocerâmica de quatro marcas comerciais de ligas de $\mathrm{Pd}-\mathrm{Ga}$, utilizando uma liga de $\mathrm{Pd}-\mathrm{Ag}$ como controle. Para realização dos testes foram confeccionados espécimes achatados, que foram jateados e oxidados. A cerâmica foi aplicada em uma área circular no centro de cada placa e fraturada utilizando-se forças de flexão constante. Todas as falhas ocorreram no término da região cerâmica sem a observação de fraturas por tensão da mesma. As ligas de Pd-Ga demonstraram resultados semelhantes aos obtidos anteriormente com ligas de Pd-Cu-Ga. Segundo os autores, nos testes de flexão até hoje propostos, os resultados numéricos não correspondem à verdadeira resistência de união metalocerâmica por não levarem em conta os módulos de elasticidade dos materiais. Para a avaliação e mensuração da resistência de união, o teste deve provocar a separação da camada de cerâmica na região da interface e não falhas de tensão (fraturas coesivas) devidas a esforços desenvolvidos na superfície cerâmica. 


\section{PROPOSIÇÃO}

Utilizando a metodologia descrita por CHONG; $\mathrm{BEECH}$; $\mathrm{CHEM}^{19} \mathrm{em}$ 1980, modificada por BATISTA ${ }^{7}$ em 1997, a qual utiliza testes de cisalhamento, buscou-se:

1. Avaliar a resistência de união metalocerâmica entre três sistemas cerâmicos odontológicos: Ceramco (Ceramco Inc., EUA), Noritake (Noritake Kizai Co., Japão) e Vita VMK-68 (Vita Zahnfabrik, Alemanha); com uma liga de paládioprata (Pors-on 4, Degussa S.A., Brasil).

2. Comparar os valores de resistência de união dos três sistemas e analisar possíveis diferenças existentes entre as três marcas. 


\section{MATERIAIS E MÉTODOS}

Neste trabalho utilizaram-se uma liga de paládio-prata (Pors-on 4 Degussa S.A., Guarulhos, São Paulo, Brasil) e três sistemas cerâmicos: Ceramco (Ceramco Inc., Burlington, NJ, USA), Noritake Super Porcelain EX-3 (Noritake Kizai Co., Ltd., Nagoia, Japão) e Vita VMK-68 (Vita Zahnfabrik, Sackingen, Alemanha).

Para a confecção dos corpos de prova, aplicação da camada cerâmica e a realização dos testes de resistência ao cisalhamento, utilizoutse uma matriz de aço inoxidável, em forma cilíndrica com 30mm de diâmetro e $20 \mathrm{~mm}$ de comprimento, tendo uma perfuração central de $6,5 \mathrm{~mm}$ de profundidade e $6 \mathrm{~mm}$ de diâmetro (Figuras 1 e 3). Uma perfuração auxiliar com $2 \mathrm{~mm}$ de diâmetro foi confeccionada desde a base da matriz até a base da perfuração central e serviu para a remoção dos padrões e corpos de prova com o auxílio de um pino metálico.
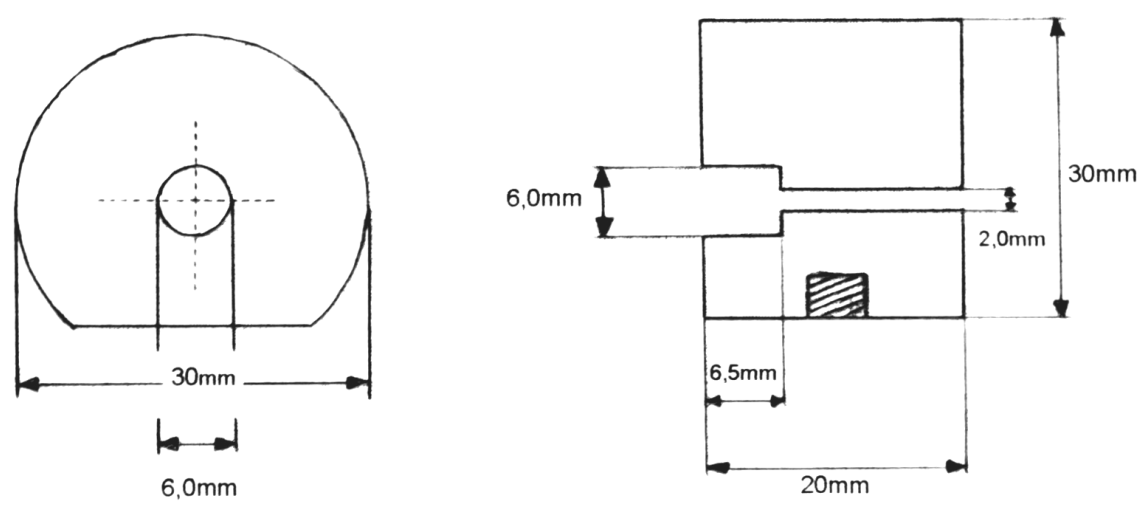

Figura 1- Esquema das dimensões da matriz de aço inoxidável 


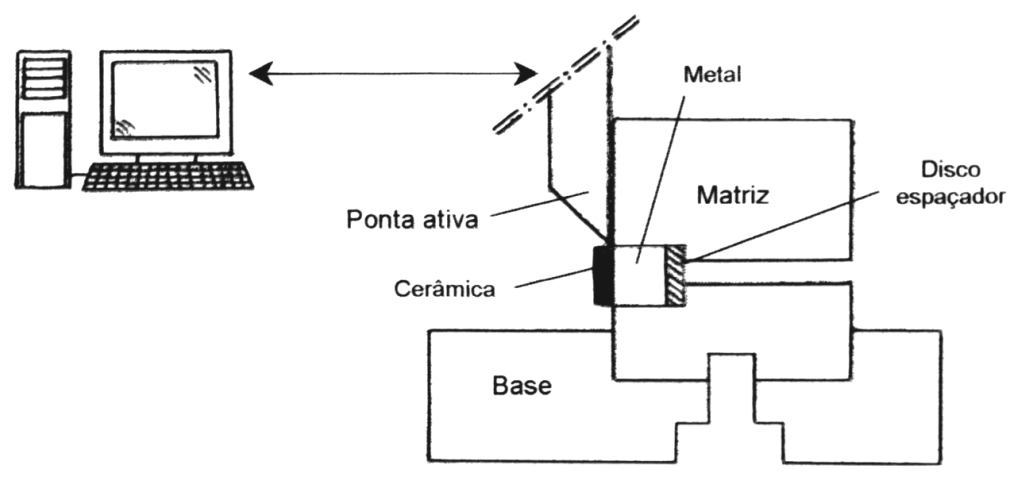

Figura 2- Esquema da configuração do teste de cisalhamento

O conjunto de componentes da matriz é composto ainda por uma base metálica à qual a matriz é parafusada para adaptação na máquina de ensaios e por um disco de $6 \mathrm{~mm}$ de diâmetro por $1,5 \mathrm{~mm}$ de espessura, que corresponde à espessura da camada de cerâmica. Desta forma, foram obtidos corpos de prova padronizados com dimensões de $6 \mathrm{~mm}$ de diâmetro, $5 \mathrm{~mm}$ de espessura de metal e 1,5mm de espessura de cerâmica (Figuras 2 e 4).

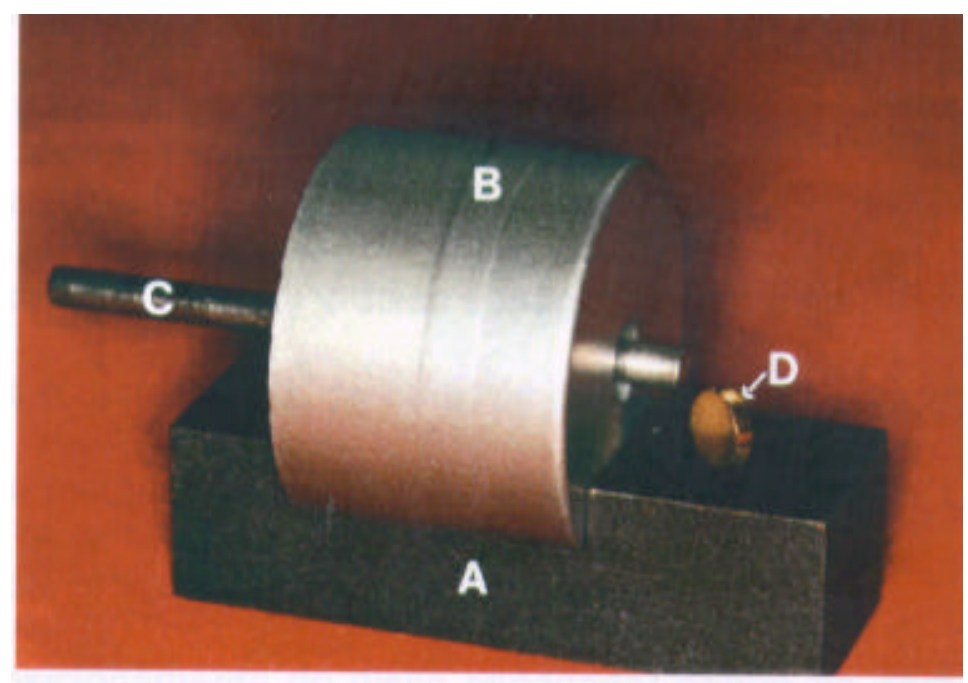

Figura 3 - Conjunto de componentes da matriz:

$A$ - Base para adaptação à maquina de ensaios

$B$ - Matriz de aço inoxidável

C - Pino metálico para remoção dos padrões e corpos de prova

D - Disco espaçador para padronização dos corpos de prova 


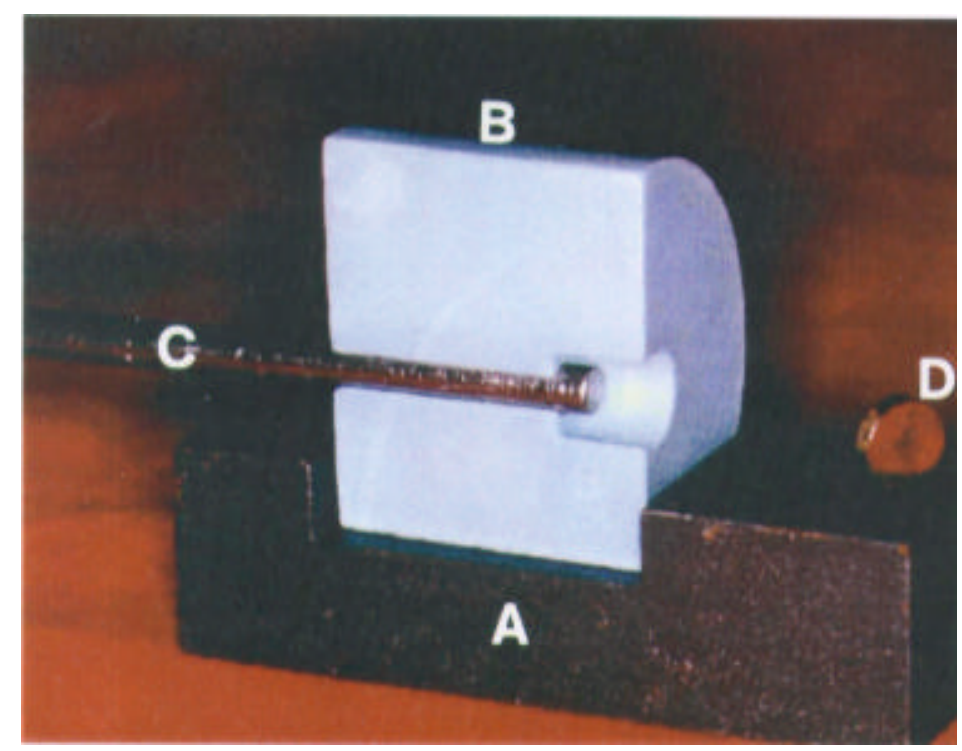

Figura 4 - Corte esquemático do conjunto de componentes da matriz:

$A$ - Base para adaptação à maquina de ensaios

B - Matriz de aço inoxidável (em corte)

C - Pino metálico para remoção dos padrões e corpos de prova

D - Disco espaçador para padronização dos corpos de prova

\subsection{Confecção dos padrões de cera}

Foram confeccionados ao todo 30 corpos de prova, obtidos a partir de padrões de cera (Cera verde regular - Kota Ind. e Com. Ltda., São Paulo, Brasil). Esta era liquefeita em estufa a $75^{\circ} \mathrm{C}$ e vertida com o auxílio de um conta-gotas no interior da matriz de aço, estando o disco espaçador dentro da mesma.

Após o resfriamento da cera, os padrões foram removidos por meio da introdução do pino metálico na perfuração auxiliar e armaze nados em um recipiente com água até os procedimentos de inclusão e fundição.

O posicionamento do disco espaçador dentro da perfuração da matriz determinou as dimensões dos padrões de cera em $6 \mathrm{~mm}$ de diâmetro e $5 \mathrm{~mm}$ de espessura (Figuras 5 e 6$)$. 


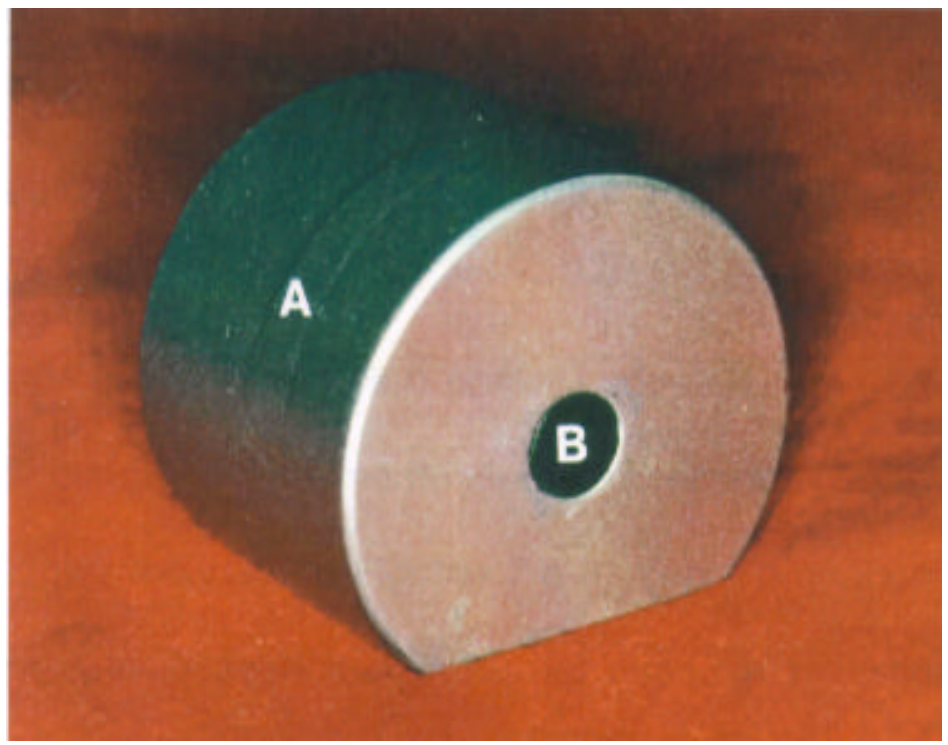

Figura 5

- A - Matriz de aço inoxidável

B - Padrão de cera posicionado no interior da matriz

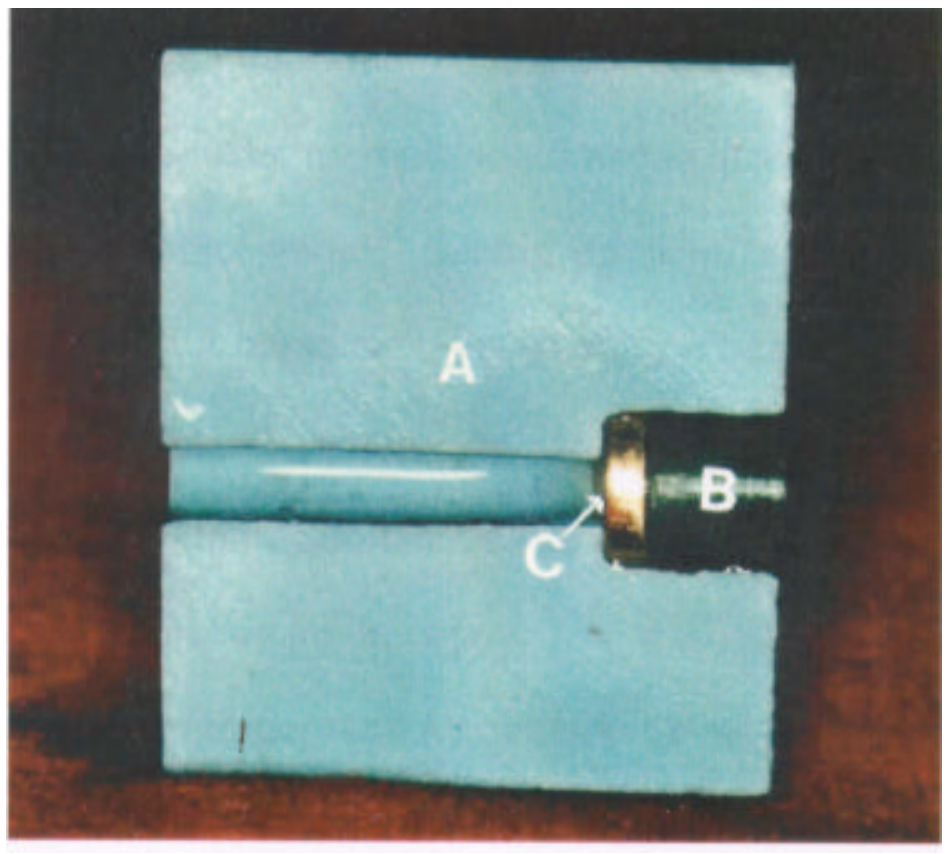

Figura 6 - A - Corte esquemático da matriz de aço inoxidável

B - Padrão de cera posicionado no interior da matriz

C- Disco espaçador posicionado 


\subsection{Inclusão e fundição}

Os padrões de cera foram incluídos em grupos de dez espécimes num mesmo anel de fundição.

Os padrões de cera foram posicionados em uma base formadora de cadinho, presos por condutos de alimentação pré-fabricados (Speedy Sprue System - Phoenix Technologies Inc., USA) (Figuras 7 e 8), sobre a qual um anel de silicone era adaptado. Para a inclusão dos padrões foi usado o revestimento à base de cerâmica granulada Micro Fine 1700 (Talladium Inc., USA). Foram utilizadas as proporções indicadas pelo fabricante para a fundição de metais preciosos: $11 \mathrm{ml}$ de líquido $+11 \mathrm{ml}$ de água destilada $(22 \mathrm{ml}$ de líquido total) para um pacote de $90 \mathrm{~g}$ de pó. O líquido foi colocado na cuba de borracha e o pó acrescentado sobre o mesmo, sendo inicialmente espatulado de forma manual por 15 segundos para incorporação do pó com o líquido. Em seguida, foi realizada a espatulação mecânica a vácuo por 60 segundos, sendo então vertido dentro do anel sob vibração mecânica. Decorridos 30 minutos para a presa do revestimento, a base formadora de cadinho foi retirada e o revestimento levado ao forno elétrico (EDG-FA IV, EDG Equipamentos e Controles Ltda., São Carlos - SP, Brasil) à temperatura de $300^{\circ} \mathrm{C}$ durante 60 minutos, para eliminação da cera.

Em seguida, a temperatura foi aumentada até $900^{\circ} \mathrm{C}$ por um período de 60 minutos para o pré-aquecimento do bloco de revestimento.

O procedimento de fundição foi realizado com uma máquina centrífuga (J. Safrany, São Paulo - SP, Brasil) com cinco voltas em sua mola e um maçarico de furos múltiplos utilizando uma mistura de propano-oxigênio e pressão indicados pelo 
fabricante. Após a fundição, o bloco de revestimento foi deixado em temperatura ambiente até atingir o resfriamento total. Por fim, utilizou-se uma serra para dividir o bloco de revestimento sem comprometer o metal em seu interior e os resíduos de revestimento foram removidos com um jato de óxido de alumínio com pressão de 80 Ib/pol (Trijato - Odonto Larcon, Maringá - PR, Brasil).

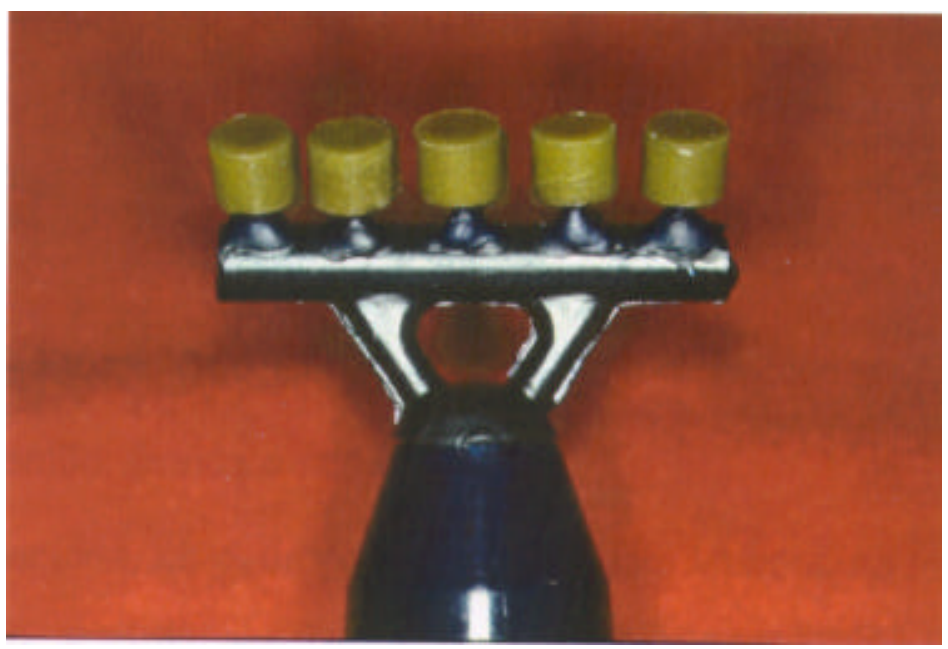

Figura 7- Posicionamento dos padrões de cera no pino formador de condutos de alimentação

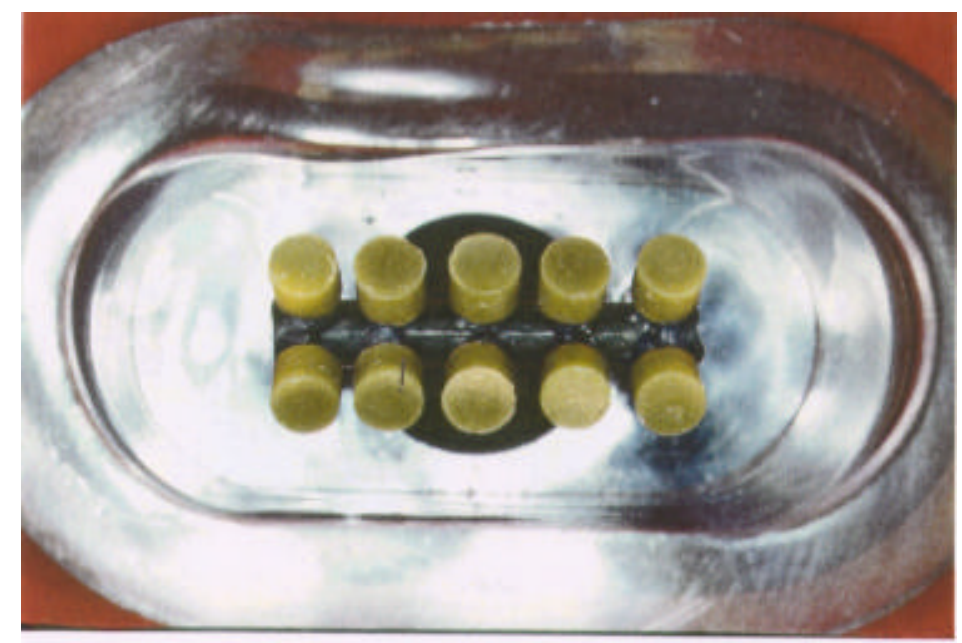

Figura 8- Posicionamento do conjunto dentro do anel de silicone 


\subsection{Tratamento dos padrões metálicos}

As peças metálicas foram limpas de todos os resíduos de revestimento com a utilização de espátulas de Hollemback, Le Cron, brocas de aço e pontas de óxido de alumínio (Figura 9). Tiveram seus condutos de alimentação cortados com discos e pedras de óxido de alumínio (Dentorium Inc., NY, USA) em motor de baixa rotação e passaram por ajustes de remoção de excessos e adaptação no interior da matriz (Figuras 10 e 11).

Após a perfeita adaptação na matriz os padrões foram limpos em aparelho ultra-sônico, lavados em água corrente e jateados com óxido de alumínio $50 \mu \mathrm{m}$ (Microjato - Bioart, São Carlos, Brasil) para a homogeneização da textura superficial, sendo então, limpos e secos.

Em seguida, os padrões metálicos foram levados ao forno e aquecidos a $980^{\circ} \mathrm{C}$ sem vácuo durante dez minutos, para a oxidação da superfície. Por fim, foram lavados em água destilada e secos, não sendo mais tocados até a aplicação da cerâmica.

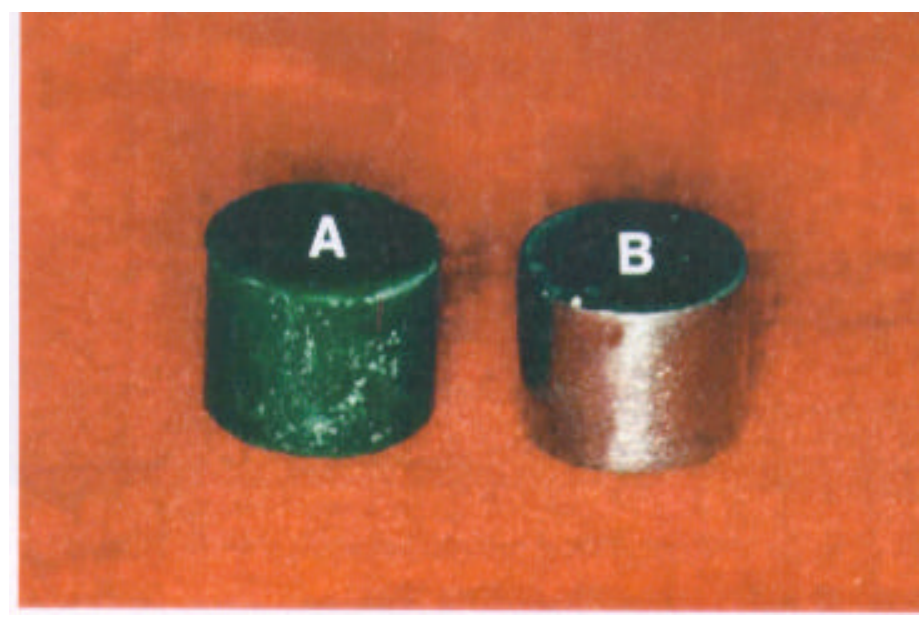

Figura 9 - A - Padrão de cera

B - Padrão metálico 


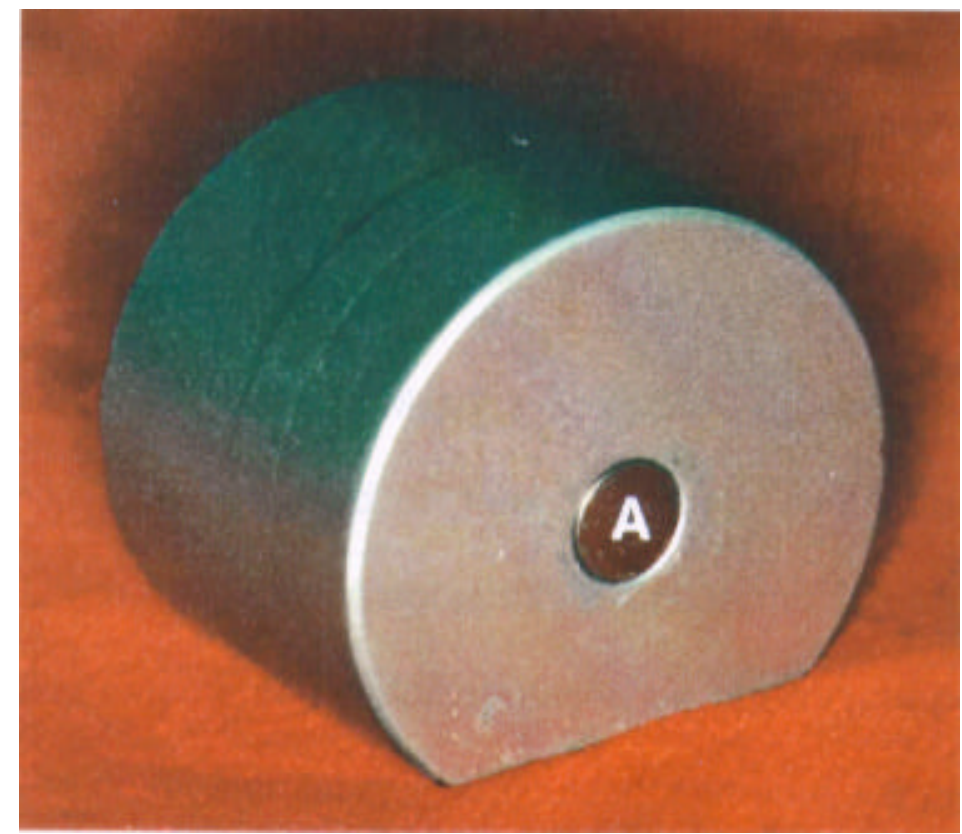

Figura 10 - Padrão metálico adaptado e posicionado no interior da matriz

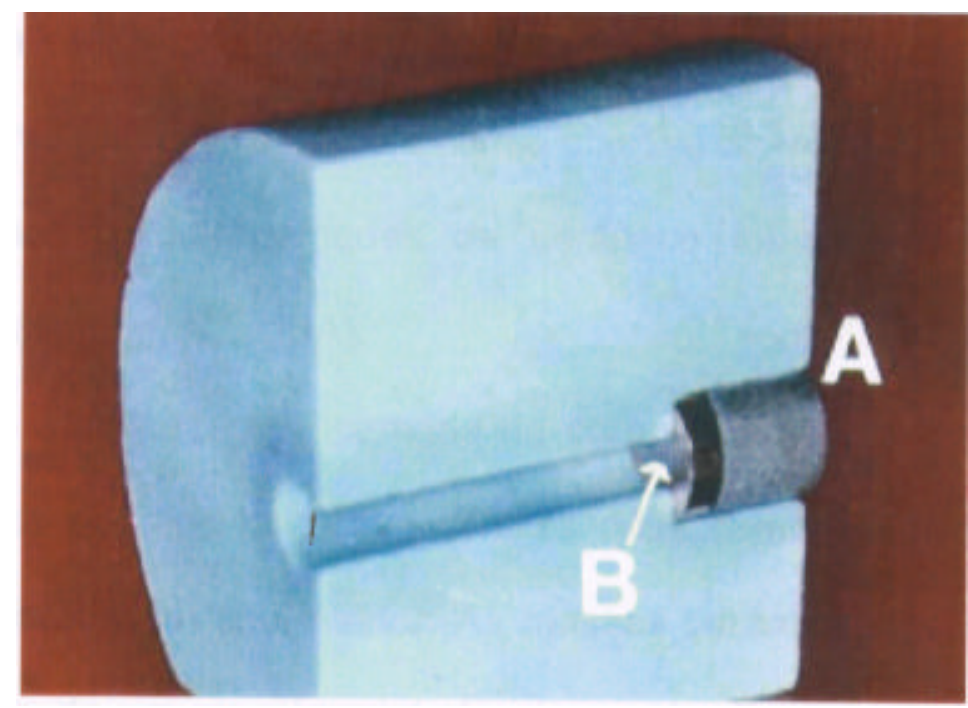

Figura 11 - Corte esquemático mostrando:

A - Padrão metálico adaptado no interior da matriz

B - Disco espaçador posicionado 


\subsection{Aplicação da cerâmica}

Os três sistemas cerâmicos foram aplicados de acordo com as instruções de cada fabricante para preparo das massas, condensação, temperatura e tempo de cocção.

Primeiramente, foram aplicados os opacos de cada sistema. O opaco do sistema Ceramco é apresentado na forma de pasta enquanto os opacos dos sistemas Noritake e Vita VMK-68 são apresentados na forma de pó/líquido.

Independentemente da apresentação do opaco (em pó ou em pasta), uma primeira camada do mesmo foi aplicada cuidadosamente. Os padrões metálicos foram seguros com o auxílio de uma pinça para facilitar a preensão e, com a utilização de um pincel de pelos macios, os opacos foram aplicados em pequenas quantidades, de forma a "molhar" a superfície do metal com cerâmica, garantindo a perfeita união entre esta e a liga, sendo em seguida queimados. Após o resfriamento, uma segunda camada foi aplicada, de forma semelhante à primeira, mas agora com uma espessura maior e com o objetivo de mascarar o metal.

A queima das camadas de cerâmica foi feita no forno Phoenix (Ceramco Inc., Burlington, NJ, USA).

Para a aplicação da camada de corpo a matriz foi posicionada sobre uma bancada e os padrões metálicos com as duas camadas de cerâmica opaca foram então adaptados em seu interior. As massas cerâmicas foram preparadas e aplicadas por meio de um pincel no interior da matriz. Os excessos de água foram removidos com lenços absorventes e a condensação da cerâmica foi feita com pressão manual, de acordo com as técnicas de condensação da cerâmica. 
Em seguida à aplicação, os corpos de prova foram removidos cuidadosamente (Figura 12) e levados ao forno para serem queimados de acordo as instruções de cada fabricante (Tabela 1). Após o resfriamento, passaram por uma avaliação para a observação de possíveis imperfeições, bolhas ou falhas de aplicação. Aqueles que necessitaram de ajustes foram recolocados na matriz e uma segunda camada de cerâmica foi aplicada.

Após a conclusão de todos os corpos de prova (Figura 13), os mesmos foram adaptados à matriz de modo que somente a porção cerâmica permaneceu de fora, com a finalidade de se aplicar a força na interface metalocerâmica (Figura 14).

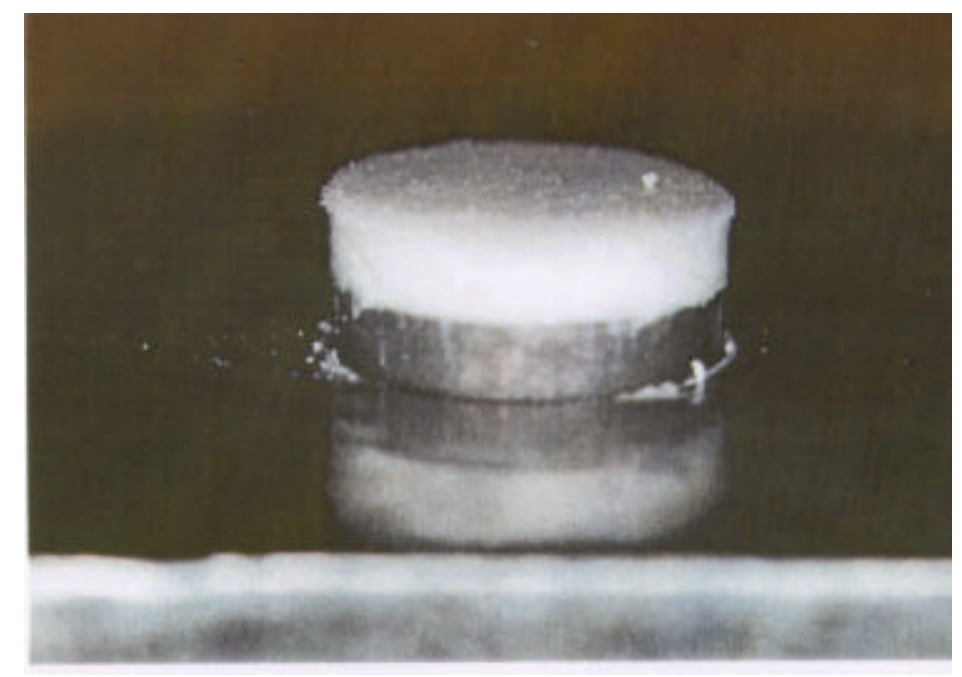

Figura 12 - Remoção do padrão metálico com a camada de cerâmica aplicada 
Tabela 1 - Temperaturas e tempos de queima dos sistemas cerâmicos.

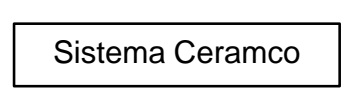

\begin{tabular}{l|cccc}
\hline & Pré-secagem & T inicial & ${ }^{\circ} \mathrm{C} / \mathrm{min}$ & T final \\
\hline $1^{\circ}$ camada opaco & $3 \mathrm{~min}$ & $500^{\circ} \mathrm{C}$ & $200^{\circ} \mathrm{C}$ & $975^{\circ} \mathrm{C}$ \\
$2^{\mathrm{a}}$ camada opaco & $3 \mathrm{~min}$ & $650^{\circ} \mathrm{C}$ & $70^{\circ} \mathrm{C}$ & $970^{\circ} \mathrm{C}$ \\
$1^{\mathrm{a}}$ camada corpo & $5 \mathrm{~min}$ & $650^{\circ} \mathrm{C}$ & $70^{\circ} \mathrm{C}$ & $940^{\circ} \mathrm{C}$ \\
$2^{\mathrm{a}}$ camada corpo & $5 \mathrm{~min}$ & $650^{\circ} \mathrm{C}$ & $70^{\circ} \mathrm{C}$ & $940^{\circ} \mathrm{C}$ \\
\hline
\end{tabular}

Sistema Noritake

\begin{tabular}{l|cccc}
\hline & Pré-secagem & T inicial & ${ }^{\circ} \mathrm{C} / \mathrm{min}$ & T final \\
\hline $1^{3}$ camada opaco & $2-5 \mathrm{~min}$ & $700^{\circ} \mathrm{C}$ & $55^{\circ} \mathrm{C}$ & $960^{\circ} \mathrm{C}$ \\
$2^{\mathrm{a}}$ camada opaco & $3 \mathrm{~min}$ & $700^{\circ} \mathrm{C}$ & $55^{\circ} \mathrm{C}$ & $960^{\circ} \mathrm{C}$ \\
$1^{\text {a }}$ camada corpo & $7-15 \mathrm{~min}$ & $600^{\circ} \mathrm{C}$ & $45^{\circ} \mathrm{C}$ & $930^{\circ} \mathrm{C}$ \\
$2^{\text {a }}$ camada corpo & $7-15 \mathrm{~min}$ & $600^{\circ} \mathrm{C}$ & $45^{\circ} \mathrm{C}$ & $930^{\circ} \mathrm{C}$ \\
\hline
\end{tabular}

\begin{tabular}{l|cccc}
\hline & Pré-secagem & $T_{\text {inicial }}{ }^{\circ} \mathrm{C} / \mathrm{min}$ & $T$ final \\
\hline $1^{\mathrm{a}}$ camada opaco & $0 \mathrm{~min}$ & $650^{\circ} \mathrm{C}$ & $52^{\circ} \mathrm{C}$ & $960^{\circ} \mathrm{C}$ \\
$2^{\mathrm{a}}$ camada opaco & $0 \mathrm{~min}$ & $650^{\circ} \mathrm{C}$ & $52^{\circ} \mathrm{C}$ & $960^{\circ} \mathrm{C}$ \\
$1^{\mathrm{a}}$ camada corpo & $6 \mathrm{~min}$ & $650^{\circ} \mathrm{C}$ & $52^{\circ} \mathrm{C}$ & $940^{\circ} \mathrm{C}$ \\
$2^{\mathrm{a}}$ camada corpo & $6 \mathrm{~min}$ & $650^{\circ} \mathrm{C}$ & $52^{\circ} \mathrm{C}$ & $940^{\circ} \mathrm{C}$ \\
\hline
\end{tabular}

\section{Sistema Vita VMK 68}

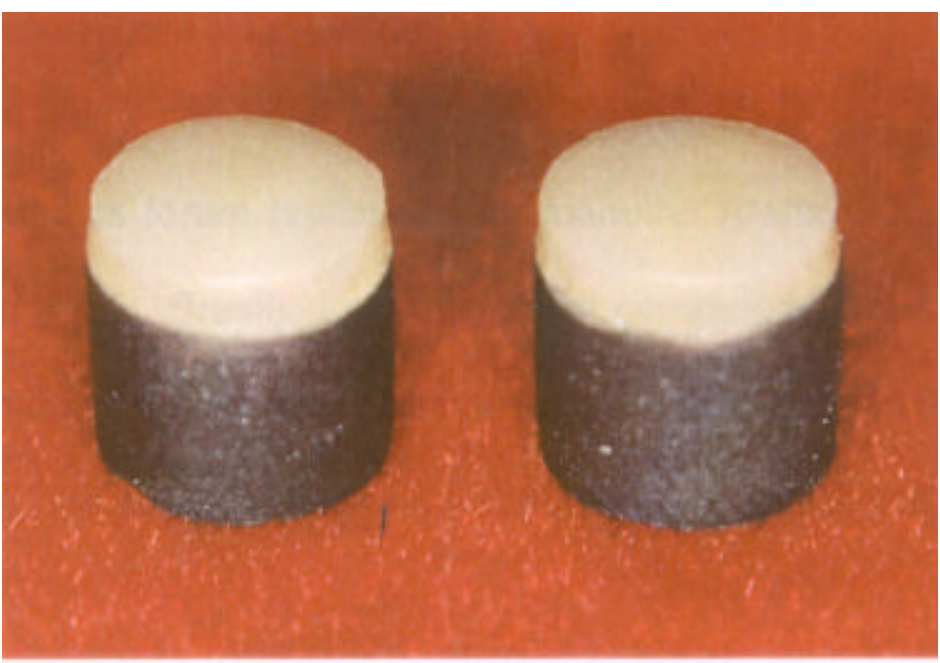

Figura 13 - Corpos de prova concluídos 


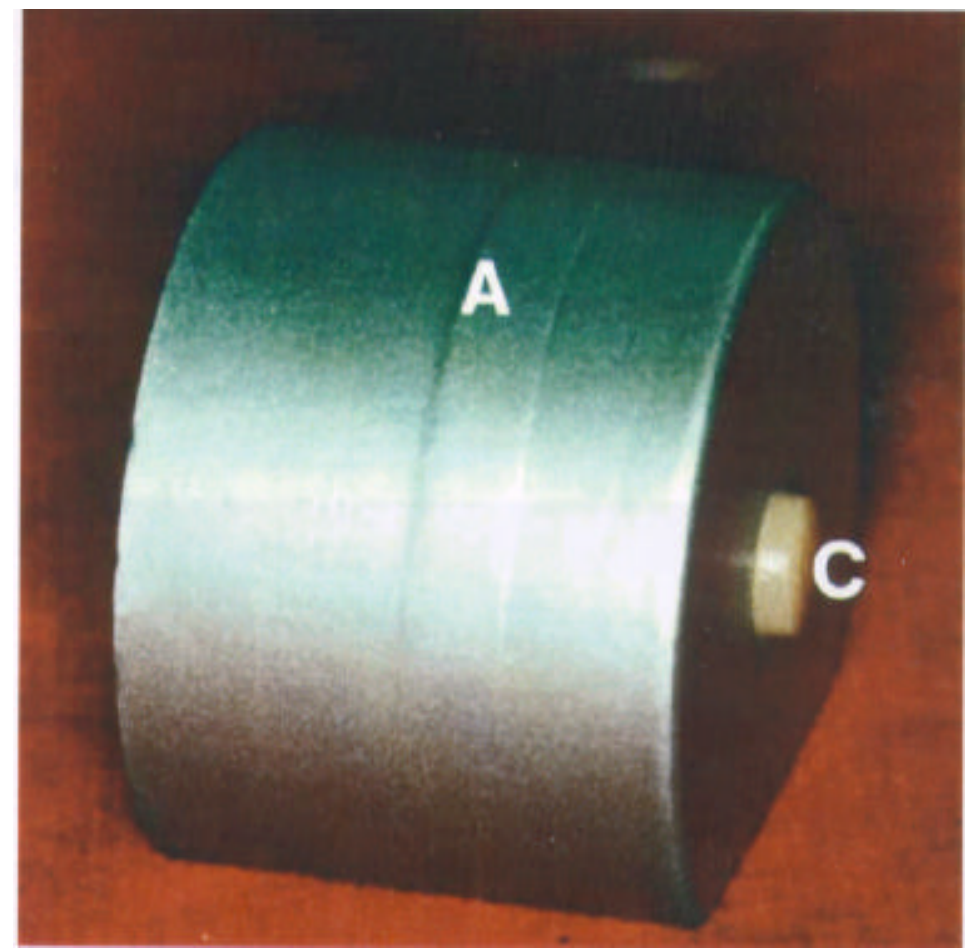

Figura 14 - Com o disco espaçador posicionado, apenas a porção cerâmica permanece para fora

\subsection{Testes de resistência ao cisalhamento}

Os ensaios foram realizados na máquina Kratos 2000 (Dinamômetros Kratos, São Paulo - SP, Brasil), controlada por computador, que possui diversos programas e executa bdos os movimentos automaticamente, inclusive fornecendo ao final dos testes, um relatório com os resultados e gráficos das forças aplicadas (Figura 2).

Uma ponta ativa em forma de hemicunha com $0,5 \mathrm{~mm}$ de espessura foi conectada à célula de carga e com velocidade de $0,5 \mathrm{~mm}$ por minuto, realizou a compressão vertical (Figura 15) até o momento da ruptura, quando então 
interrompeu o movimento e registrou na tela o valor da força máxima aplicada em kgf. Em seguida, a máquina retornou à posição inicial e se colocou em modo de espera até o próximo teste. O procedimento foi repetido para todos os trinta corpos de prova.

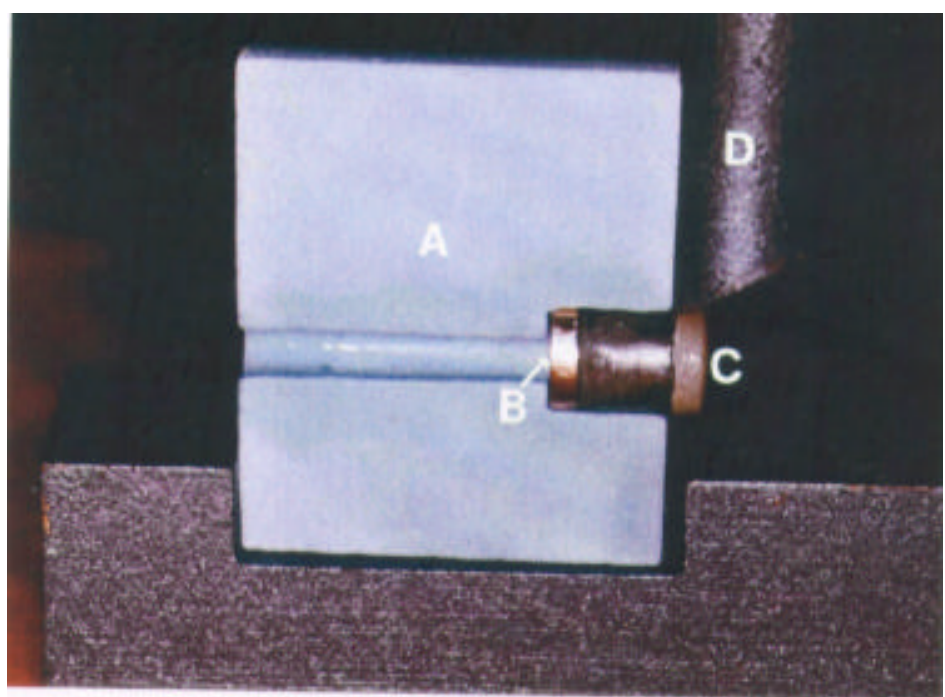

Figura 15 - A- Corte esquemático da da matriz de aço inoxidável

B - Disco espaçador posicionado

C - Porção cerâmica recebendo a força de compressão

D - Ponta ativa exercendo pressão sobre a interface 


\section{RESULTADOS}

\subsection{Resultados obtidos}

Após a fratura dos espécimes, os valores de resistência obtidos eram apresentados pela máquina de ensaios em quilograma-força (kgf), necessitando serem convertidos em MPa.

Para a conversão dos dados foram utilizadas as seguintes razões:

$$
1 \mathrm{kgf}=9,803 \mathrm{~N} \quad 1 \mathrm{MPa}=1 \mathrm{MN} / \mathrm{m}^{2} \quad 1 \mathrm{MPa}=0,154 / 10^{3} \mathrm{lb} / \mathrm{pol}^{2}
$$

Na conversão dos resultados de kgf para MPa, existe a necessidade de se conhecer a área da superfície testada. Para a obtenção das áreas de superfície dos corpos de prova, utilizou-se a medição com um paquímetro digital de precisão centesimal (Mitutoyo - Japão). Os dados das dimensões foram informados ao computador que controlava a máquina de ensaios, que converteu os valores nas áreas de cada espécime.

Os valores calculados para as áreas de cada espécime podem ser vistos na Figura 16, que demonstra a grande homogeneidade das medidas obtidas, devido à padronização conseguida com a utilização da matriz de aço inoxidável e excelente capacidade de adaptação da liga.

Devido à pequena variação das áreas, este não foi um fator influente nos resultados de resistência de união. 


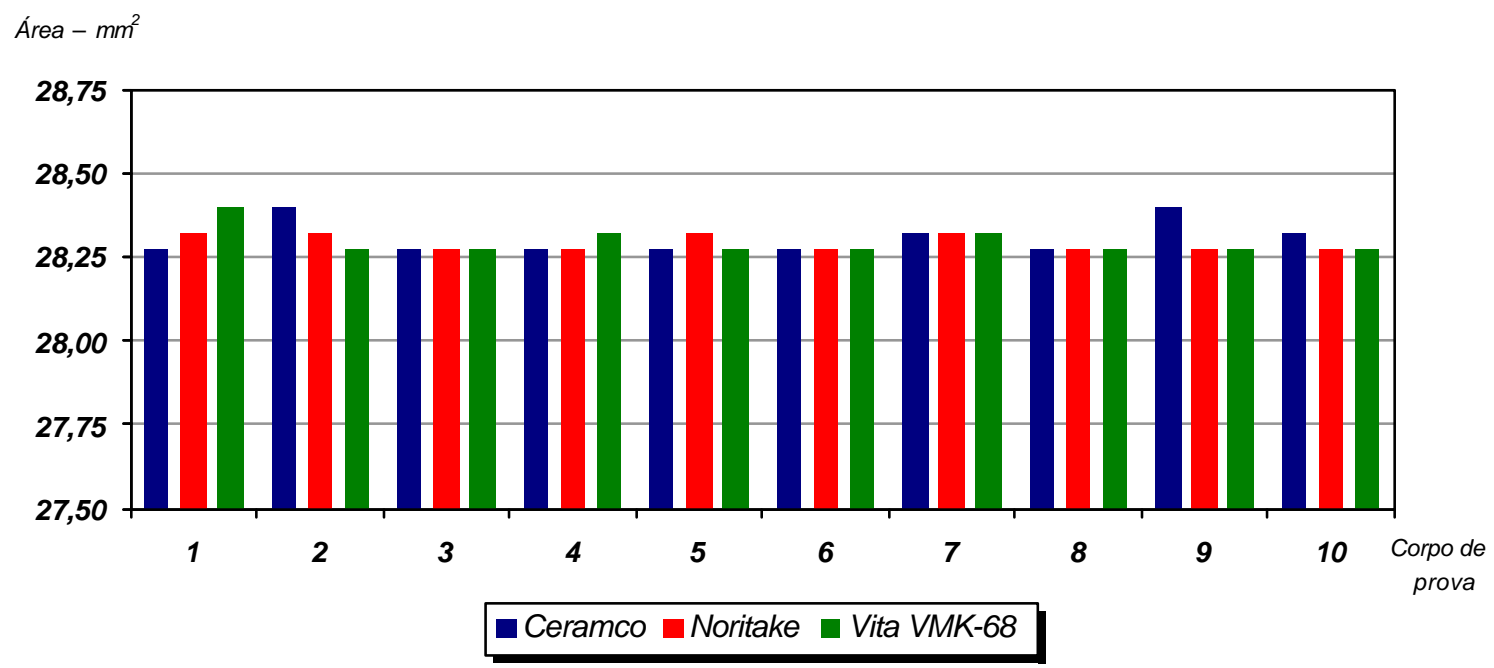

Figura 16 - Áreas de superfície de união dos corpos de prova para os três sistemas cerâmicos

Os valores das médias de resistência ao cisalhamento foram, em ordem decrescente, obtidos com os sistemas cerâmicos Noritake, Ceramco e Vita VMK - 68. Os resultados obtidos nos testes de resistência de união para cada sistema testado podem ser vistos nas Tabelas 2, 3 e 4 .

Tabela 2 - Valores obtidos em MPa para os testes de resistência ao cisalhamento com os corpos de prova do sistema Ceramco (duas camadas de opaco em pasta + duas camadas de corpo)

\begin{tabular}{c|c|c}
\hline $\begin{array}{c}\text { Amostra } \\
\text { Ceramco }\end{array}$ & Área $\left(\mathbf{m m}^{\mathbf{2}}\right)$ & Resistência de união - MPa \\
\hline 1 & 28,27 & 32,95 \\
\hline 2 & 28,40 & 23,75 \\
\hline 3 & 28,27 & 34,15 \\
\hline 4 & 28,27 & 38,17 \\
\hline 5 & 28,27 & 18,53 \\
\hline 6 & 28,27 & 20,80 \\
\hline 7 & 28,32 & 32,67 \\
\hline 8 & 28,27 & 28,69 \\
\hline 9 & 28,40 & 32,44 \\
\hline 10 & 28,32 & 19,97 \\
\hline Média & $\mathbf{2 8 , 3 0}$ & $\mathbf{2 8 , 2 0}$ \\
\hline
\end{tabular}


Tabela 3 - Valores obtidos em MPa para os testes de resistência ao cisalhamento com os corpos de prova do sistema Noritake (duas camadas de opaco em pó + duas camadas de corpo)

\begin{tabular}{c|c|c}
\hline $\begin{array}{c}\text { Amostra } \\
\text { Noritake }\end{array}$ & Área $\mathbf{( m m}^{\mathbf{2})}$ & Resistência de união - MPa \\
\hline 1 & 28,32 & 35,96 \\
\hline 2 & 28,32 & 38,18 \\
\hline 3 & 28,27 & 36,63 \\
\hline 4 & 28,27 & 16,52 \\
\hline 5 & 28,32 & 26,34 \\
\hline 6 & 28,27 & 23,04 \\
\hline 7 & 28,32 & 20,21 \\
\hline 8 & 28,27 & 38,16 \\
\hline 9 & 28,27 & 19,62 \\
\hline 10 & 28,27 & 34,97 \\
\hline Média & $\mathbf{2 8 , 3 0}$ & $\mathbf{2 8 , 9 6}$ \\
\hline
\end{tabular}

Tabela 4 - Valores obtidos em MPa para os testes de resistência ao cisalhamento com os corpos de prova do sistema Vita-VMK 68 (duas camadas de opaco em pó + duas camadas de corpo)

\begin{tabular}{c|c|c}
\hline $\begin{array}{c}\text { Amostra } \\
\text { Vita VMK-68 }\end{array}$ & Área $\left(\mathbf{m m}^{\mathbf{2})}\right.$ & Resistência de união - MPa \\
\hline 1 & 28,40 & 19,43 \\
\hline 2 & 28,27 & 13,85 \\
\hline 3 & 28,27 & 25,55 \\
\hline 4 & 28,32 & 30,94 \\
\hline 5 & 28,27 & 29,21 \\
\hline 6 & 28,27 & 26,68 \\
\hline 7 & 28,32 & 15,50 \\
\hline 8 & 28,27 & 26,96 \\
\hline 9 & 28,27 & 21,36 \\
\hline 10 & 28,27 & 31,62 \\
\hline Média & $\mathbf{2 8 , 3 0}$ & $\mathbf{2 4 , 1 1}$ \\
\hline
\end{tabular}

Os valores das médias e desvios padrão para todos os sistemas e corpos de prova testados, são demonstrados no Figura 17. 


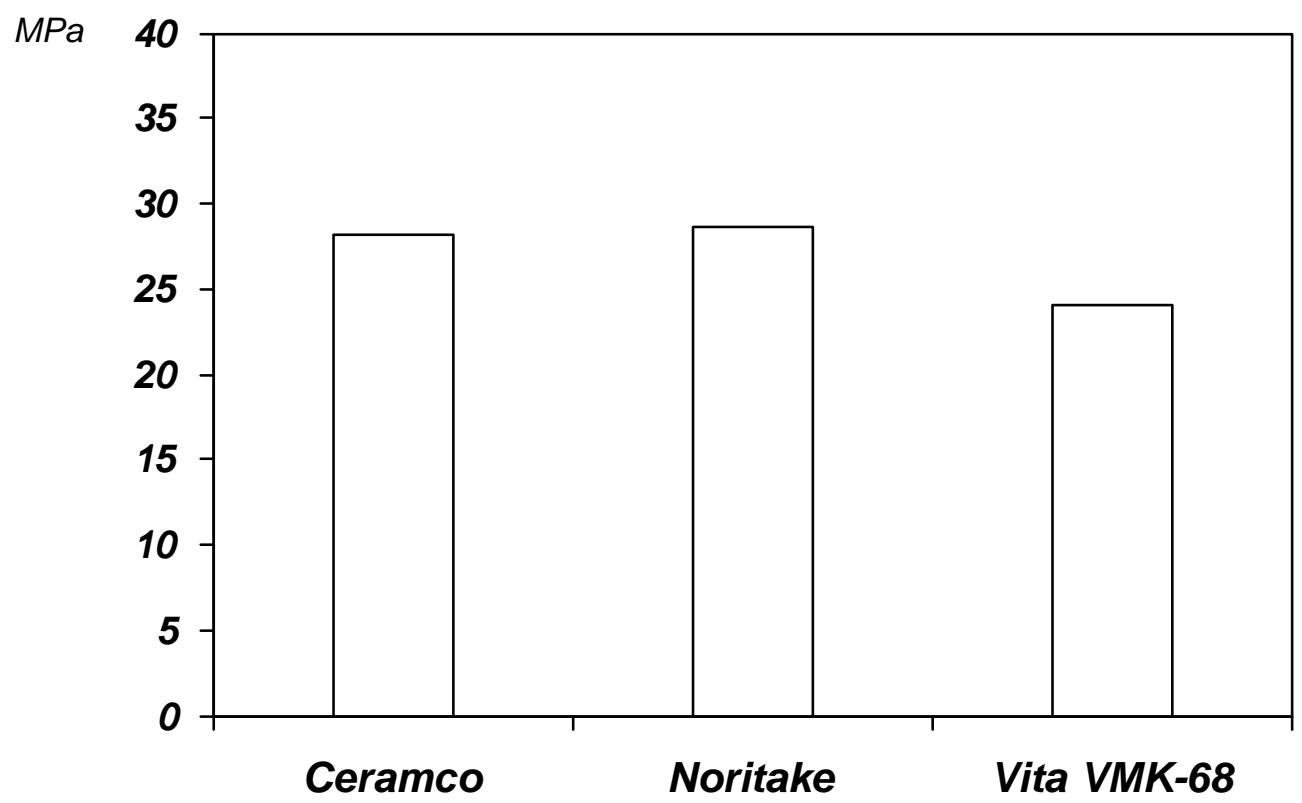

Figura 17 - Resistência de união metalocerâmica dos corpos de prova para os três sistemas cerâmicos

\subsection{Análise estatística}

Primeiramente, foram determinados os padrões amostrais e normalidade dos resultados. Estes resultados são apresentados na Tabela 5.

Como o objetivo do trabalho foi verificar a existência ou não de diferenças significantes entre os valores de resistência de união metalocerâmica para os três diferentes sistemas cerâmicos fixando-se a variável liga, utilizourse a análise de variância a um critério. $(\alpha=0,05)$ 
Tabela 5 - Parâmetros amostrais

\begin{tabular}{cccc}
\hline Material & Média (x) & Desvio padrão & Mediana \\
\hline Ceramco & 28,212 & 6,923 & 30,565 \\
\hline Noritake & 28,693 & 8,654 & 30,655 \\
\hline VMK-68 & 24,110 & 6,278 & 26,115 \\
\hline$p=0,299$
\end{tabular}

$p=0,299$

Para as médias obtidas no teste de variância a um critério de avaliação, obteve-se um valor de $p=0,299$, não havendo portanto, diferença estatisticamente significante entre elas. 


\section{DISCUSSÃO}

Desde o início da utilização das restaurações metalocerâmicas, existiu uma grande preocupação com a avaliação da quantidade e qualidade da resistência de união entre o metal e a cerâmica.

Esta preocupação traduzia-se na procura de um tipo de teste para avaliar a resistência de união metalocerâmica e se este simularia as condições encontradas na cavidade oral e nos sistemas metalocerâmicos.

Vários foram os testes utilizados para este fim, dentre eles os que utilizaram tensões de cisalhamento, como os preconizados por - SHELL; NIELSEN ${ }^{54}$ em 1963; KNAP; RYGE ${ }^{30}$ em 1966; VICKERY; BADINELL ${ }^{60}$ em 1968; ANTHONY et al. ${ }^{1}$ em 1970; NALLY ${ }^{45}$ em 1972; LUBOVICH; GOODKIND ${ }^{36}$ em 1977; CHONG; BEECH; CHEM ${ }^{19}$ em 1980; CHIODI NETO ${ }^{18}$ em 1981; BATISTA ${ }^{7}$ em 1997. Outros testes utilizaram tensões de tração, como os preconizados por KELLY; ASGAR; O'BRIEN²9 em 1969; SCED; MCLEAN ${ }^{53}$ em 1972; outros ainda, tensões de flexão - LAVINE; CUSTER ${ }^{35}$ em 1966; MACKERT et al. em 1976; CAPUTO; DUNN; REISBICK ${ }^{13}$ em 1977; e, finalmente, os que utilizaram tensões de torção, como os preconizados por CARTER; AL-MUDAFAR; SORENSEN ${ }^{14}$ em 1979; HERØ; SYVERUD ${ }^{26}$ em 1985.

O teste de SHELL; NIELSEN ${ }^{54}$ tem sido muito utilizado ${ }^{12,18,21,22,23,49}$ para a avaliação da resistência de união, pois sua metodologia consiste na aplicação 
de uma camada de cerâmica em forma de semicírculo em torno do padrão metálico, evitando, segundo os autores, tensões sobre a cerâmica.

Mais recentemente, CHIODI $\mathrm{NETO}^{18}$ realizou um trabalho onde modificou o teste proposto por SHELL; NIELSEN ${ }^{54}$, numa tentativa de desenvolver um ensaio que pudesse avaliar a resistência de união metalocerâmica em toda a sua plenitude.

A despeito da quantidade de tipos de testes existentes, em 1980, ANUSAVICE et al. $^{2}$ publicaram um trabalho de avaliação da distribuição de estresses interfaciais pela análise de elemento finito, associado a 11 diferentes tipos de testes existentes e chegaram à conclusão de que para um teste fornecer resultados precisos de avaliação da união metalocerâmica, estes devem preencher dois requisitos básicos: (1) A concentração de estresses deve acontecer somente ao longo da interface. Se o teste produz concentrações de estresses além da interface, como por exemplo na terminação da camada de cerâmica ou alterações na espessura dessa camada, os resultados obtidos serão menores do que a verdadeira resistência de união metalocerâmica. (2) A quantidade de tensões presentes deveria ser zero, pois quando há a presença desse tipo de força, há a possibilidade de fratura na cerâmica e de "contaminação" dos valores resultantes do teste.

Para a realização deste trabalho, utilizou-se o teste proposto por CHONG; BEECH; $\mathrm{CHEM}^{19}$, modificado por BATISTA ${ }^{7}$, o qual propicia facilidade de confecção e padronização dos espécimes a serem submetidos aos testes. Além 
disso, a matriz utilizada na confecção dos corpos de prova serve para a realização dos testes de cisalhamento. De acordo com os requisitos descritos por CHONG; BEECH; $\mathrm{CHEM}^{19}$, este tipo de teste é bastante confiável e permite que a união da interface metalocerâmica seja o único tipo de adesão.

Além disso, há um constante aprimoramento dos sistemas cerâmicos, que apresentam cada vez mais elevados valores de resistência quando submetidos aos mais variados tipos de testes. Ao mesmo tempo, esses sistemas cerâmicos apresentam-se clinicamente melhorados, com pequena quantidade de falhas devidas à fratura, que é sem sombra de dúvida a característica mais indesejável a que este tipo de material está sujeito.

Simultaneamente à melhoria das cerâmicas, ocorreu uma explosão no que diz respeito ao senso estético por parte dos pacientes, os quais exercem uma pressão constante para que seus tratamentos protéticos sejam confeccionados em cerâmica, em detrimento de metais ou resinas, não levando em conta características funcionais e parafuncionais que podem gerar tensões sobre os materiais cerâmicos, ocasionando insucessos ${ }^{7}$.

Inicialmente, apenas ligas nobres eram utilizadas para a confecção de restaurações metalocerâmicas e estas ligas ocupavam um lugar de destaque na Odontologia, mas com os crescentes preços do ouro, buscaram-se alternativas mais baratas para a sua substituição. As ligas seminobres e não-nobres tiveram e ainda têm uma grande utilização, mesmo sendo de manipulação mais crítica devido às 
características de oxidação e por apresentarem resultados de resistência de união mais baixos que as ligas nobres.

Essa busca para um substituto do ouro provocou o aparecimento, por volta dos anos 80 , das ligas à base de paládio 9 . O início de sua utilização deu-se de maneira basicamente empírica, sendo necessários muitos testes para a avaliação de sua compatibilidade com os sistemas cerâmicos existentes.

Por meio desses estudos $4,9,26,37,46,61$, descobriu-se que as ligas de paládio são adequadas para a utilização odontológica e que possuem vantagens e desvantagens em relação a outros tipos de ligas nobres e não-nobres.

Vários autores têm estudado a resistência de união metalocerâmica e sua dependência de diferentes fatores como: tempo e temperatura de cocção ANUSAVICE; RINGLE; FAIRHURST ${ }^{4}$; DAFTARY; DONOVAN ${ }^{20}$; RILEY ${ }^{50}$; textura do metal - LAVINE; CUSTER ${ }^{35}$; LUBOVICH; GOODKIND ${ }^{36}$; RILEY50; utilização de diferentes tipos de opaco ou agentes de união - ANUSAVICE $^{5}$; RILEY $50 ;$ SILVER; KLEIN; HOWARD ${ }^{55}$; e oxidação prévia - ANUSAVICE; RINGLE; FAIRHURST ${ }^{4}$; FERNANDES NETO21,22.

Estudos como o de MACKERT; RINGLE; FAIRHURST ${ }^{37}$; VRIJHOEF; VAN DER ZEL ${ }^{61}$, mostram que as ligas de paládio não apresentam a formação de camada de óxidos superficiais durante o aquecimento ou resfriamento na fundição. Como a união metalocerâmica depende desta camada de óxidos para que exista a 
união química, considerada como primária, deve então existir uma outra forma de adesão entre essa liga e a cerâmica. Observou-se, que as ligas de Pd-Ag apresentam a formação de nódulos superficiais durante o processo de fundição, e seria por meio do imbricamento da cerâmica nessas irregularidades superficiais da liga, a via de ligação entre os dois materiais, ou seja, a principal forma de união entre a cerâmica e esse tipo de liga é a mecânica. Segundo ANUSAVICE ${ }^{5}$, essa condição não tem aparentemente produzido um número significante de falhas clínicas, o que garante a qualidade da união. Contudo, existem outros elementos na composição da liga, como a prata e o estanho, que são oxidáveis. Dessa forma, o procedimento de oxidação prévia é necessário para a formação de óxidos destes elementos oxidáveis, de forma que mesmo em pequena quantidade, a presença destes óxidos contribua para a resistência de união.

O que pôde ser observado nesta pesquisa, é que apesar de alguns estudos $^{37,61}$ não indicarem presença de óxidos superficiais, tampouco considerarem a característica de oxidação das ligas de paládio, a resistência de união mostrourse satisfatória com a oxidação indicada pelo fabricante. Em adição a isso, uma explicação para a qualidade da união mesmo sem uma oxidação importante, é a caraterística da liga Pors-on 4 possuir grãos com dimensões reduzidas $(7 \mu \mathrm{m})$ quando comparada a outras ligas de Pd-Ag $(180 \mu \mathrm{m})$. Esse tamanho reduzido dos grãos da liga é conseguido pela incorporação de refinadores de grãos, que são metais, geralmente rutênio e irídio, com ponto de fusão mais elevado do que os principais componentes da liga. Durante a fusão, os refinadores permanecem no estado sólido e à medida que a liga sofre o resfriamento, essas partículas atuam 
como núcleos de cristalização. O crescimento dos cristais é interrompido rapidamente, o que cria um número muito grande de pequenos cristais. Ao contrário, se não há a adição dos refinadores, existirão poucos núcleos de cristalização, o que resultará na formação de um pequeno número de cristais, com tamanho elevado. As vantagens de se obter uma liga com grãos de pequenas dimensões, residem na melhoria de qualidades mecânicas, tais como dureza, resistência e elasticidade, além de uma maior superfície de contato externa. Como a liga não apresenta uma formação de óxidos suficiente para considerar-se a união química, a retenção mecânica torna-se o fator primário de união metalocerâmica. Portanto, nada mais lógico do que se obter uma liga com grãos pequenos e que possibilitam uma grande superfície de contato com a cerâmica.

Como a liga Pors-on 4 deve ser pré-oxidada a $980^{\circ} \mathrm{C}$ durante dez minutos, a exposição à atmosfera em altas temperaturas, promove um afloramento de nódulos superficiais compostos por $\mathrm{Pd}$ e $\mathrm{Ag}$, o que resulta na vaporização da prata. Essa volatilização da prata tem sido observada em experimentos com as ligas de Pd-Ag e considerada como a responsável pela perda de peso destas ligas quando submetidas a temperaturas superiores a $900^{\circ} \mathrm{C}$, sendo diretamente proporcional à quantidade de prata na liga. Um outro fator negativo causado pela volatilização da prata é a descoloração ou manchamento da cerâmica. A contaminação pelos vapores de prata é considerada a causa mais provável para a pigmentação esverdeada ou acinzentada observada em algumas restaurações confeccionadas com ligas de Pd-Ag. Estudos "in vitro" demonstram a coloração de cerâmicas posicionadas $2 \mathrm{~mm}$ distante da liga. Isso pode ser explicado pelo 
transporte do vapor de prata associado ao oxigênio presente, e pode também ser considerado como o responsável por este tipo de pigmentação. Além disso, o mecanismo industrial de pigmentação do vidro por prata pode explicar o processo do manchamento da cerâmica. A prata metálica depositada sobre a superfície do vidro por evaporação, não migra para dentro do vidro quando todo o sistema é aquecido à vácuo, mas com a incorporação de oxigênio, a reação é iniciada. A prata move-se dentro do vidro por meio de trocas iônicas com átomos de sódio. O íon de prata é incolor, e para que ocorra a coloração, deve sofrer um processo de redução, originando como produto a prata metálica. Como os processos de evaporação da prata e troca iônica dependem da presença de oxigênio, alguns laboratórios utilizam blocos de grafite colocados dentro dos fornos durante a queima da cerâmica, numa tentativa de minimizar a influência desse fenômeno. $\mathrm{O}$ oxigênio presente no interior do forno tende a reagir com o carbono do grafite e formar $\mathrm{CO}$, impossibilitando as reações do mesmo com a cerâmica.

Após os procedimentos de cocção dos três sistemas cerâmicos, não foram observadas alterações na coloração da camada cerâmica em nenhum dos corpos de prova. Apenas após a realização dos testes de cisalhamento, pôde-se observar um pequeno tom acinzentado na camada de opaco do sistema Vita VMK68. Muitos autores são de opinião de que a descoloração é devida à dissolução de óxido de prata na camada cerâmica. Dessa forma, apenas as ligas de Pd-Ag são capazes de provocar este efeito. Em contrapartida, apenas algumas cerâmicas mostram o fenômeno da descoloração ou manchamento, outras não. Atualmente, a maioria dos fabricantes de cerâmicas, produz sistemas cerâmicos resistentes ou 
livres de descoloração, em resposta ao uso comum de ligas contendo prata. Provavelmente, a coloração da cerâmica Vita VMK-68 ocorreu por este ser um sistema introduzido já há mais tempo do que os sistemas Ceramco e Noritake. Contudo, apesar da coloração estar presente, esta não ultrapassou a camada de opaco, não comprometendo a coloração original da cerâmica.

Uma outra característica das ligas de paládio, é a alta sensibilidade à absorção de carbono durante os procedimentos de fundição. Problemas como porosidades na cerâmica e contaminação por carbono na liga são descritos por HERO; SYVERUD ${ }^{26}$; BÖNING; WALTER . Esta dissolução é diretamente proporcional ao aumento da temperatura e ao conteúdo de paládio da liga, isto é, maior será a dissolução, quanto maior for a temperatura ou a quantidade de paládio presente. $\mathrm{O}$ carbono precipita-se na forma de grafite quando ocorre a solidificação do paládio, durante o resfriamento da estrutura fundida. Além da diminuição na resistência, maleabilidade e ductilidade da liga, a presença de carbono promove uma série de reações com elementos das cerâmicas durante sua cocção, reações estas que terão como resultado principal, a formação de monóxido de carbono (CO). A formação de $\mathrm{CO}$ na interface durante a cocção da cerâmica provocará o aparecimento de bolhas, que se distribuirão por toda a superfície em quantidades maiores ou menores dependendo da quantidade de CO presente. Essas bolhas contribuem para a porosidade na camada de cerâmica, que por sua vez podem levar a insucessos como fraturas ou trincas. De acordo com um estudo de BÖNING; WALTER ${ }^{9}$, essa influência sobre a resistência metalocerâmica é pequena, mas deve 
ser considerada. Como prevenção para este tipo de problema, recomenda-se a utilização de revestimentos livres de carbono (grafite).

Neste trabalho, utilizourse um revestimento à base de cerâmica granulada, e após a fundição, durante a remoção dos padrões metálicos do bloco de revestimento, observourse que a superfície do metal apresentava-se bastante regular e sem sinais de alterações acontecidas durante a fundição. Sob inspeção macroscópica, o metal não mostrou sinais de reações ou oxidação e o material de revestimento desprendeurse facilmente, evidenciando uma superfície metálica bastante regular e com aspecto homogêneo. Prova disso, é que foram necessários apenas pequenos ajustes com pedras e discos abrasivos para o perfeito encaixe dos padrões metálicos no orifício da matriz.

Quando analisada a resistência de união metalocerâmica entre a liga Pors-on 4 e os sistemas Ceramco, Noritake e Vita VMK-68, não foram encontradas diferenças significantes entre os valores de união para os diferentes sistemas. Os valores de resistência de união encontrados para o sistema Noritake ( $x=28,96$ $\left.\mathrm{MPa} / \mathrm{mm}^{2}\right)$ são em média $2,63 \%$ maiores que os valores do sistema Ceramco $(\mathrm{x}=28,20$ $\left.\mathrm{MPa} / \mathrm{mm}^{2}\right)$ e $16,75 \%$ maiores que os do sistema Vita $\left(\mathrm{X}=24,11 \mathrm{MPa} / \mathrm{mm}^{2}\right)$. Apesar da diferença nas médias, o teste de análise de variância de um critério determinou como não significante a diferença entre esses valores, para p=0,299.

Apesar de os resultados deste trabalho não demonstrarem diferenças significantes na comparação da resistência de união entre os três sistemas, a 
análise numérica dos resultados individuais de cada grupo, somada às características da infra-estrutura, sugere que o sistema Noritake provavelmente teria um melhor desempenho quando analisada a resistência de união entre as cerâmicas e a infra-estrutura como um todo.

Quando são analisados os valores para cada grupo isoladamente, observa-se uma grande variação entre os resultados dentro desse mesmo grupo. Esta grande variação nos resultados deve-se, provavelmente, à maneira como a cerâmica é aplicada, ou seja, apesar de a metodologia conseguir uma padronização de todos os passos da técnica, a aplicação da cerâmica é realizada de maneira manual. As massas são aplicadas no interior da matriz por meio de um pincel, e a condensação da cerâmica é feita utilizando-se lenços de papel absorvente e pressão manual. Como não há um meio de padronizar a pressão exercida manualmente durante a condensação, acredita-se que esta seja a fonte das variações nos resultados intragrupo.

Clinicamente, a interpretação dos resultados sugere que todos os sistemas possuem uma resistência de união suficiente para serem utilizados rotineiramente. Para que se obtenha um resultado satisfatório, a infra-estrutura deve possuir forma e espessura corretas e uniformes, permitindo a cobertura de toda a sua superfície externa pela camada cerâmica, a fim de favorecer o aparecimento de forças compressivas. Essas forças compressivas originam-se devido à diferença entre os coeficientes de expansão térmica entre o metal e a cerâmica, sendo que o da liga é ligeiramente maior. Dessa forma, o metal contrai-se mais rapidamente 
durante o seu resfriamento, desde a temperatura de cocção até a temperatura ambiente. $\mathrm{O}$ fato de o metal contrair-se mais que a cerâmica, permite que incidam sobre esta, tensões residuais de compressão, provendo uma forma de resistência adicional.

A análise do tipo de fratura também foi realizada, sendo considerado para esta avaliação, o aspecto macroscópico dos corpos de prova após a realização dos testes. O que pôde ser observado é que houve uma homogeneidade do tipo de fratura ocorrido. Em todos os espécimes submetidos aos testes, as fraturas ocorridas foram do tipo adesiva, isto é, com separação entre o metal e a cerâmica. De acordo com a literatura $5,28,30,37,46,61$, é este tipo de fratura que ocorre mais freqüentemente. A observação da superfície após a fratura mostrou ainda, pequenas porções onde não houve separação entre metal e cerâmica, mas ruptura da camada cerâmica. Estas "ilhotas" de cerâmica presentes na superfície do metal não são suficientes para transformar a fratura em coesiva, mas demonstram que em determinadas regiões a resistência de união é maior do que em outras, podendo ser considerada ainda como um artefato do tipo de teste.

As próteses metalocerâmicas possuem ainda como principal causa de fracassos, o processo carioso. Porém, grande parte do sucesso deste tipo de trabalho depende da resistência de união entre metal e cerâmica. Portanto, se o dente for preparado adequadamente, proporcionando retentividade e desgaste suficientes a fim de se obter uma camada de cerâmica com espessura uniforme, e os materiais utilizados possuírem compatibilidade entre os coeficientes de expansão 
térmica, conclui-se que esse tipo de trabalho depende fundamentalmente da capacidade de união entre os dois materiais, sem sofrer fadiga ou fraturas, sob diferentes condições. 


\section{CONCLUSÃO}

Considerando os dados obtidos e as análises realizadas, podemos concluir que:

7.1 A metodologia descrita mostrourse eficaz para a avaliação da resistência de união metalocerâmica entre a liga de paládio-prata e os sistemas cerâmicos selecionados para o estudo.

7.2 De acordo com as médias de resistência de união obtidas em MPa para os sistemas Ceramco $(x=28,212)$, Noritake $(x=28,963)$ e Vita VMK-68 $(x=24,110)$, não foi encontrada diferença estatística $(p<0,05)$.

7.3 Os resultados de resistência de união dos três sistemas cerâmicos com a liga escolhida foram considerados satisfatórios e em concordância com a literatura, servindo como subsídio para a utilização de qualquer um dos sistemas cerâmicos avaliados em conjunto com a referida liga. 


\section{REFERÊNCIAS BIBLIOGRÁFICAS*}

1- ANTHONY, D.H. et al. Shear test for measuring bonding in cast gold alloy-porcelain composite. J. dent. Res., v.49, n.1, p.27-33, Jan./Feb. 1970.

2- ANUSAVICE, K.J. Noble metal alloys for metal-ceramic restorations. Dent. Clin. N. Amer., v.29, n.4, p.789-803, Oct. 1985.

3- ANUSAVICE, K.J.; DEHOFF, P.H.; FAIRHURST, C.W. Comparative evaluation of ceramic-metal bond tests using finite element stress analysis. J. dent. Res., v.59, p.608-13, 1980.

4- ANUSAVICE, K.J.; HORNER, J.A.; FAIRHURST, C.W. Adherence controlling elements in ceramo-metal system. I. Precious alloys. J. dent. Res., v.56, n.9, p.1045-52, Sept. 1977.

5- ANUSAVICE, K.J.; RINGLE, R.D.; FAIRHURST, C.W. Adherence controlling elements in ceramo-metal system. II. Nonprecious alloys. J. dent. Res., v.56, n.9, p.1053-61, Sept. 1979.

6- BASSMAN, A.H. Baked porcelain fused to gold. Forth. Rev. Chicago dent. Soc., v.42, n.1, p.11-2, 1961.

\footnotetext{
* Normas recomendadas para uso no âmbito da Universidade de São Paulo, com base no documento "Referências Bibliográficas: exemplos", emanado do Conselho Supervisor do Sistema Integrado de Bibliotecas da USP, em reunião de 20 de setembro de 1990.
} 
7- BATISTA, J.G. Avaliação da resistência de união metalocerâmica utilizando os sistemas opacos em pasta, convencional e agente de união. Ribeirão Preto, 1997. 102p. Dissertação (Mestrado) - Faculdade de odontologia de Ribeirão Preto, Universidade de São Paulo.

8- BERTOLOTTI, R.L. Porcelain to metal bonding. In: MCLEAN, J.W. Dental ceramics. Proccedings of the first symposium on ceramics. Chicago, Quintessence, 1983. p. 415.

9- BÖNING, K.; WALTER, M. Palladium alloys in prosthodontics: selected aspects. Int. dent. J., v.40, n.5, p.289-97, 1990.

10- BOWERS, J.E.; VERMILYEA, S.G.; GRISWOLD, W.H. Effect of metal conditioners no porcelain-alloy bond strength. J. prosth. Dent., v.54, n.2, p.201-3, Aug. 1985.

11- BRECKER, S.C. Porcelain baked to gold - a new medium in prosthodontics. J. prosth. Dent., v.6, n.6, p.801-10, Nov. 1956.

12- BULLEN CABRERA, A.E. Avaliação da resistência de união de uma liga nacional de Ni-Cr com quatro sistemas cerâmicos. Bauru, 1991. 77p. Dissertação (Mestrado) Faculdade de Odontologia de Bauru, Universidade de São Paulo.

13- CAPUTO, A.A.; DUNN, B.; REISBICK, M.H. A flexural method for evaluation of metalceramic bond strengths. J. dent. Res., v.56, n.12, p.1501-6, Dec. 1977. 
14- CARTER, J.M.; AL-MUDAFAR, J.; SORENSEN, S.E. Adherence of a nickel-chromium alloy and porcelain. J. prosth. Dent., v.41, n.2, p.167-72, Feb. 1979.

15- CARPENTER, M.; GOODKIND, R.J. Effect of varying surface texture on bond strength of one semiprecious and one nonprecious ceramo-alloy. J. prosth. Dent., v.42, n.1, p.86-95, July 1979.

16- CASCONE, P.J. Oxide formation on palladium alloys and its effects on porcelain adherence. J. dent. Res., v.62, p.255, 1983./Abstract/

17- CASCONE,P.J.; MASSIMO, M.; TUCILLO, J.J. Theoretical interfacial reactions responsible for bonding in porcelain-to-metal systems. Part II: Oxidation of alloys. J. dent. Res., v.57, p.292. Special issue. /Abstract n.872/

18- CHIODI NETTO, J. Avaliação da resistência de união da porcelana aplicada sobre liga de Ni-Cr e sobre solda. Bauru, 1981. 91p. Tese (Livre-Docência) - Faculdade de Odontologia de Bauru, Universidade de São Paulo.

19- CHONG, M.P.; BEECH, D.; CHEM, C. A simple shear test to evaluate the bond strength of ceramic fused to metal. Aust. dent. J., v.25, n.6, p.357-61, Dec. 1980.

20-DAFTARY, F.; DONOVAN, T. Effect of four pretreatment techniques on porcelain-tometal bond strength. J. prosth. Dent., v.56, n.5, p.535-9, Nov. 1986. 
21- DEKON, S.F.C. Avaliação da resistência de união metalocerâmica em função de diferentes ciclos de oxidação prévia. Bauru, 1994. Dissertação (Mestrado) Faculdade de Odontologia de Bauru, Universidade de São Paulo.

22- FERNADES NETO, A.J. Efeito da refundição na resistência de união com a porcelana em uma liga de níquel-cromo. Bauru, 1982. Dissertação (Mestrado) Faculdade de Odontologia de Bauru, Universidade de São Paulo.

23- FERNANDES NETO, A.J. Avaliação da resistência de união de três sistemas de porcelana odontológica aplicados sobre três ligas metálicas a base de níquelcromo e uma a base de cromo-cobalto contendo titânio. Ribeirão Preto, 1996. 103p. Tese (Doutorado) - Faculdade de Odontologia de Ribeirão Preto, Universidade de São Paulo.

24- HAMMAD, I.A.; TALIC, Y.F. Designs of bond strength tests for metal-ceramic complexes: review of the literature. J. prosth. Dent., v.75, n.6, p.602-8, June 1996.

25- HAMMAD, I.A.; GOODKIND, R.J.; GERBERICH, W.W. A shear test of bond strength of ceramometals. J. prosth. Dent., v.58, n.4, p.431-7, Oct. 1987.

26- HERØ, H.; SYVERUD, M. Carbon impurities and properties of some palladium alloys for ceramic veneering. Dent. Mat., v.1, p.106-10, 1985. 
27- JOHNSTON, J.F.; DYKEMA, R.W.; CUNNINGHAM, D.M. The use and construction of gold crowns with a fused porcelain venner: A progress report. J. prosth. Dent., v.6, n.6, p.811-21, Nov. 1956.

28-JOHNSTON, J.F.; DYKEMA, R.W.; CUNNINGHAM, D.M. Porcelain veneers fused to cast gold crowns. J. Amer. dent. Ass., v.57, p.48-53, 1958.

29- KELLY, M.; ASGAR, K.; O'BRIEN, W.J. Tensile strength determination of the interface between porcelain fused to gold. J. Biomed. Mat. Res., v.3, n.3, p.403-8, Sept. 1969.

30-KNAP, F.J.; RYGE, G. Study of bond strength of dental porcelain fused to metal. J. dent. Res., v.45, n.4, p.1`047-51, July/Aug. 1966.

31- LACY, A.M. The chemical nature of dental porcelain. Dent. Clin. N. Amer., v.21, n.4, p.661-7, Oct. 1977.

32- LANDEZ, C. Le point de vue du céramiste. Actualités odontostomat., v.109, n.3, p.3653, Mar. 1975.

33- LANZA, M.D. Avaliação da influência da oxidação prévia à aplicação da porcelana na resistência de união porcelana/metal em duas ligas de $\mathrm{Ni}-\mathrm{Cr}$ (Durabond e Unibond) com dois tipos de opaco (Paint-On 68 e Paint-On 88). Bauru, 1982. 97p. Tese (Doutorado) - Faculdade de Odontologia de Bauru, Universidade de São Paulo. 
34- LAUTENSCHLAGER, E.P.; GREENER, E.H.; ELKINGTON, W.E. Microprobe analysis of gold porcelain bonding. J. dent. Res., v.48, p.1206, 1969.

35- LAVINE. M.H.; CUSTER, F. Variables affecting the strength of bond between porcelain to gold. J. dent. Res., v.45, n.1, p.32-6, Jan./Feb. 1966.

36- LUBOVICH, R.P.; GOODKIND, R.J. Bond strength studies of precious, semiprecious and nonprecious ceramic-metal alloys with two porcelains. J. prosth. Dent., v.37, n.3, p.288-99, Mar. 1977.

37- MACKERT, J.R.; RINGLE, R.D.; FAIRHURST, C.W. High-temperature behavior of a PdAg alloy for porcelain. J. dent. Res., v.62, n.12, p.1229-35, Dec. 1983.

38- MACKERT, J.R. et al. Measurement of oxide adherence to PFM alloys. J. dent. Res., v.63, n.11, p.1335-40, Nov. 1984.

39- MACKERT, J.R. et al. The relationship between oxide adherence and porcelain-metal bonding. J.dent. Res., v.67, n.2, p.474-8, Feb. 1988.

40- MALHOTRA, M.L.; MAICKEL, L.B. Shear bond strength in porcelain-metal restorations. J. prosth. Dent., v.43, n.4, p.397-400, Apr. 1980.

41- MCLEAN, J.W. The ceramo-metalic bond. In: VON FRAUNHOFER, J.A. Scientific aspects of dental materials. Boston, Butterworths, 1975. p. 307-17. 
42- MOFFA, J.P.; JENKINS, W.A. Status report on base-metal crown and bridge alloys. J. Amer. dent. Ass., v.89, n.3, p.652-5, Sept. 1974.

43-MOFFA, J.P. et al. An evaluation of nonprecious alloys for the use with porcelain veneers. Part I: Physical properties. J. prosth. Dent., v.30, n.4, p.424-31, Oct. 1973.

44- MUNFORD, G.; RIDGE, E.A. Dental porcelain. Dent. Clin. N. Amer., v.15, p. 33-42, 1971.

45- NALLY, J.N. Chemico-physical analysis and mechanical tests of ceramo-metalic complex. Int. dent. J., v.18, p.309-25, 1968.

46- ÖILO, G.; JOHANSSON, B.; SYVERUD, M. Bond strength of porcelain to dental alloys - an evaluation of two tests methods. Scand. J. dent. Res., v.89, p.289-96, 1981.

47- PAPAZOGLOU, E.; BRANTLEY, W.A. Porcelain adherence versus force to failure for palladium-gallium alloys: A critique of metal-ceramic bond testing. Dent. Mat., v.14, p.112-9, Mar. 1998.

48- PAPAZOGLOU, E. et al. Porcelain adherence to high-palladium alloys. J. prosth. Dent., v.70, n.5, p.386-94, Nov. 1993. 
49- RESKALLA, H.N.J.F. Avaliação da resistência de união da porcelana sobre quatro ligas de $\mathrm{Ni}-\mathrm{Cr}$ nacionais variando a técnica de aplicação do opaco. Bauru, 1988. 63p. Dissertação (Mestrado) - Faculdade de Odontologia de Bauru, Universidade de São Paulo.

50- RILEY, E.J. Ceramo-metal restoration state of the science. Dent. Clin. N. Amer., v.21, n.4, p.669-82, Oct. 1977.

51- ROOT, N.S.; FINDLEY, M.M. The bond between porcelain and gold alloys: caracteristics and practical considerations. Quint. dent. Tech., n.11/12, p.93-6, Nov./Dec. 1976.

52- SCARANELLO, R.M.; MUENCH, A. Contribuição ao estudo da resistência de união entre porcelanas e ligas de níquel-cromo. Rev. Pós-Grad., v.1, n.1, p.22-6, jan./mar. 1994.

53- SCED, I.R.; MCLEAN, J.W. The strength of metal/ceramic bonds with base metals containing chromium. Brit. dent. J., v.132, n.6, p.232-4, Mar. 1972.

54- SHELL, J.S.; NIELSEN, J.P. Study of the between bond gold alloys and porcelain. New Rochelle, J. F. Jelenko, 1963.

55- SILVER, M.; KLEIN, G.; HOWARD, M.C. Platinum-porcelain restaurations. J. prosth. Dent., v.6, n.5, p.695-705, Sept. 1956. 
56- SIMONPAOLI, Y. Le point de vue de clinicien. Les céramo-nickels. Rugusités de surface des infrastructures métalliques ou mini-épaulements. Actualités odontostomat., v.109, p.27-35, Mar. 1975.

57- SKINNER, E.W.; PHILLIPS, R.W. Skinner's science of dental materials. Philadelphia, Saunders, 1973. p.547.

58- SMITH, D.L. et al. Porcelain fused to gold. J. dent. Res., v.38, n.4, p.759, 1959. /Abstract/

59- STEIN, R.S.; KUWATA, M. Current ceramodental procedures. Dent. Clin. N. Amer., v.21, n.4, p.737-40, Oct. 1977.

60-VICKERY, R.C.; BADINELLI, L.A. Nature of attachment forces in porcelain-gold systems. J. dent. Res., v.47, n.5, p.683-9, Sept./Oct. 1968.

61- VRIJHOEF, M.M.A.; VAN DER ZEL, J.M. Oxidation of a gold-palladium PMF alloy. J. oral Rehabil., v.15, p.307-12, 1988.

62- VON RADNOTH, M.S.; LAUTENSCHLAGER, E.P. Metal surface changes during porcelain firing. J. dent. Res., v.48, n.2, p.321-4, 1969.

63-WAGNER, C.R. et al. Effect of interfacial variables on metal-porcelain bonding. J. Biomed. Mat. Res., v.27, p.531-7, Apr. 1993. 
64- WARPHEA, W.S.; GOODKIND, R.J. Design and technique variables affecting fracture resistance of metal-ceramic restorations. J. prosth. Dent., v.35, n.3, p.291-8, Mar. 1976.

65- WATANABE, T. Composition and morphology of oxides on porcelain fused to $\mathrm{Ni}-\mathrm{Cr}$ alloys containing Be. Aichi Gakuin Daigaku Shigakkai Shi., v.27, n.2, p.383-96, June 1989. apud BATISTA, J.G. ${ }^{7}$, p. 41.

66-WEISS, P.A. New design parameters: utilizing the properties of nickel-chromium superalloys. Dent. Clin. N. Amer., v.21, n.4, p.769-89, Oct. 1977.

67-WU, Y. et al. The effect of oxidation heat treatment on porcelain bond strength in selected base metal alloys. J. prosth. Dent., v.66, n.4, p.439-44, Oct. 1991.

68- YAMAMOTO, M. Metal-ceramics: principles and methods of Makoto Yamamoto. Chicago, Quintessence, 1985. p.106-57. 


\begin{abstract}
Bond strength of three ceramic systems and a palladium-silver alloy.
\end{abstract}

The purpose of this study was to evaluate the bond strength of a palladium-silver alloy (Pors-on 4) to three ceramic systems (Ceramco, Noritake and Vita VMK-68) using shear forces at the metalceramic interface. The method used for the tests was that developed by CHONG, BEECH e $\mathrm{CHEM}^{19}$, modified by BATISTA $^{7}$. A stainless steel cylindric matrix was used for preparation of the metal patterns, application of ceramic and to perform the shear tests. Thirty specimens were prepared consisting of a palladium-silver alloy cylinder with two layers of opaque porcelain covered by two layers of body porcelain. The shear tests were perfomed in a universal testing machine using a load cell of $100 \mathrm{kgf}$ at a cross head speed of $0,5 \mathrm{~mm} / \mathrm{min}$. The mean shear strength values for the three ceramic systems were: $28.212 \mathrm{MPa}$ (Ceramco), 28.963MPa (Noritake) and 24.110MPa (Vita VMK-68). No statistically significant diferences were found among the groups what led us to conclude that the three ceramic systems are suitable for use in combination with the selected alloy. 